Tér és Társadalom 13. évf. 1999/1-2. 1-30. p.

Tér és Társadalom

XIII. évf. 1999 1-2: 1-30

\title{
A MAGYARORSZÁGI VÁROSHÁLÓZAT ÉS AZ EU-CSATLAKOZÁS
}

\author{
(Hungarian Urban Network and the EU Accession)
}

\section{BELUSZKY PÁL - GYŐRI RÓBERT}

A magyarországi városállomány és -hálózat alakulásának, átformálódásának feltételei, mozgatórugói, irányai az elmúlt fél évszázadban is több alkalommal gyớkeresen megváltoztak. Ezen autochton eredetủ folyamatok vehetnek ismét új irányt az EU-csatlakozás előkészuletei, illetve megvalósulása nyomán.

\section{A városhálózat fejlődésének feltételei 1990 előtt}

Milyen általános vonások jellemezték a magyarországi városállományt az 1980-as évek végéig?

- Annak ellenére, hogy már 1990 elött is megjelentek ,piaci elemek" a telepúléshálózat, igy a városállomány fejlödésében (a magánvállalkozások telephelyválasztása, a regionális helyzetból fakadó elônyök, a lakosság vásárlóereje, de ide sorolható a kủlönböző ,regionális lobbyk” tevékenysége, a „tervalkuk” eredményei stb. is), a felülröl való irányítottság e téren is meghatározó szerepet játszott. A felülrōl való irányítottság nem feltétlenủl állami, kormányzati irányítást, illetve beavatkozást jelentett, hanem pl. az állami nagyvállalatok által vezényelt iparosítást, telephely-politikát, telepúlésfinanszirozást és intézmény-fenntartást. Így az ipari ủzemek tőbbnyire nem a fokozatosan felhalmozódó helyi tóke bevonásával, vagy a kisiparból kinőve jelentek meg egy-egy városban, hanem egyetlen „kőzponti” dőntés eredményeként, egyik napról a másikra megváltoztatva a települések funkcióit, pozícióit. Egyes „funkciók" letelepítése tơbbnyire nem számolt a telepủlés „elózményeivel”, adottságaival; nem folytatta a „szerves fejlödést", a tulajdonlás révén nem hozott létre szoros kapcsolatot a vállalat és a település (illetve lakói) kőzött, nem gyarapította a helyi tókét, gyakran nem szervesủlt a telephelyet adó falu vagy város gazdaságával, társadalmával. Így egy-egy üzem, iparág csỏdje, felszámolása, termelésének visszaesése ismét drasztikusan változtathatta meg egy-egy telepuilés helyzetét, fóleg a monofunkciós telepúlések, a kisvárosok és a községek életét. A helyi adottságok, erőforrások, elképzelések, a helyi társadalom milyensége háttérbe szorult a városfejlödés folyamatában, illetve csak áttételesen érvényesült (pl. egyes városok érdekérvényesítési képességén keresztull). Ehhez járult a helyi (tanácsi) bevételek jelentéktelen aránya, szerepe, a közigazgatási besorolás (megye- vagy járási székhely, város vagy kőzség) fontossága a telepủlések helyzetének alakításában. 
- A „felülről való irányítottság” is hozzájárult a városállomány homogenizálódásához, a „modellszerü” elemek terjedéséhez és a koncentrált fejlődéshez.

- A homogenizálódás és a koncentráció a nyolcvanas évek végéig a telepưlésfejlödés folyamatának általános tendenciája. A homogenizálódást támogatta a társadalom és a gazdaság irányitásának, ellátásának, az ezt szolgáló intézményhálózatnak a monopolizált helyzete, a központositott intézményeknek országosan egységes, modellszerü elosztása, funkciója stb. A pénzintézeti tevékenységet évtizedeken át a Magyar Nemzeti Bank és az OTP látta el, egységes hierarchiába foglalva, azonos hatáskörökkel, tevékenységekkel. Ilyen körülmények között, pl. „regionális pénzügyi központ” kialakulása elképzelhetetlen volt. Hasonló elvek szerint müködött az egészségügytől (itt „,normatívák” alapján határoztak az egészségügyi intézmények telepítéséről, s ugyancsak elképzelhetetlen volt, pl. több száz fogorvost eltartó „fogász-városok” kialakulása) kezdve a helyi sajtóig az államositott, ,intézményesített társadalom” szinte minden szegmense. Az állami keretekbe szoritott tevékenységek ugyanakkor koncentrációt eredményeztek, az ügyvédi munkaközösségekbe kényszerült ügyvédi tevékenységtöl a megyei sütőipari vállalatok keretében dolgozó pékekig. Koncentrálódott az agrártermelés is, legalábbis a falusi térségek szintjén (állami gazdaságok, termelőszövetkezetek üzemközpontjai). A mezővárosok erőteljes iparosítása, az iparvárosok városi intézményeinek fejlesztése azt eredményezte, hogy kevés sajátos profilú város maradt a magyarországi városállományban. Szabványositott volt a városokban kialakított intézményhálózat is, függetlenül a tényleges igényektől.

- A társadalomépités és irányitás szocialistának nevezett modelljét átható koncentrációs hajlamok és törekvések egybeestek a magyarországi urbanizációs folyamatok adott szakaszával - az ún. I. urbanizációs ciklus - együtt járó koncentrációs jelenségekkel. Ezeket a tendenciákat támogatta a településhálózattervezés s a településfejlesztés gyakorlata is. Ám az urbanizálódás - a városfejlődés, városodás - a településfejlesztó beruházások szélsőséges koncentrálása, illetve a gazdaság extenzív növekedése ellenére sem követte a városok ipari szerepkörének bỏvülését. A városok - egy részének! - látványos, gyors növekedése, a nagy volumenü, ugyancsak a városokba koncentrált lakásépítés ellenére az ország ,, alulurbanizált" állapotban maradt - legalábbis, ha a városi ipar s a központi funkciók volumenéhez mérjük azt. Az alulurbanizáltság következménye lett a tömeges ingázás. Az ország keresőinek kereken egyötöde, a községek lakosságának viszont bő kétötöde ingázóvá vált. Növelte az ingázók számát, hogy a városok közelébe igyekvö, de a városban állami lakáshoz nem jutó családok a városkörnyéki falvakba települtek át (az olcsóbb épitkezési lehetóségek, a mellékjövedelmek könnyebb megszerezhetösége, a rusztikusabb életforma csábításának-kényszerének engedve), $\mathrm{s}$ így megmaradtak az ingázók táborában. $\mathrm{E}$ folyamatoknak a településhálózatra gyakorolt hatása sokrétủ volt. Az ingázás elterjedése szinte az egész országot egyetlen hatalmas lakó-övezetté formálta, ám „valódi” agglomerálódás csak néhány helyen, elsősorban Budapest környékén lépett fel. A szocialista korszak korábbi szakaszában - ötvenes-hatvanas évek - 
a települések közötti, mindenekelött a falvak közötti különbségeket elsỏ renden a foglalkozási átrétegződés elörehaladása, az ingázás mértéke, az esetleg a községekbe telepưlt bányászkodás vagy ipar mértéke alakította ki.

- A nagyarányú ingázás kiszolgáltatottá tette a lakóövezetet, az agglomerálódó térségeket a munkahely-központjukkal szemben (ennek következményei a kitermelöipart, nehézipart sújtó válság nyomán igen súlyosak).

- A „relatív" koncentráció egyben hierarchizálódást jelentett. A megyeszékhelyek hatalmi kőzpontokká válása, a megyeszékhelyeken, valamint - a nyolcvanas évek elsỏ feléig - a járási székhelyeken felszaporodó intézmények, a falusi térségekben lezajló „körzetesitési” folyamat, a települési autonómia hiánya, a településhálózat-fejlesztés ősztönzése nyomán a fơvárostól az ún. társközségekig - a „nem tanácsi székhelyekig” - tagolt, a lakosság mindennapi életét, életkörülményeit, esélyeit stb. messzemenően befolyásoló hierarchikus láncolat alakult ki. Ez befolyásolta, irányította a migrációt, a népesedési folyamatokat, a helyi társadalmak rétegzỏdését, az ellátottsági színvonalat és így tovább. A társadalmi-foglalkozási hierarchiában való elörelépés igénye előbb-utóbb szükségessé tette a településhierarchiában való „elörelépést” is (migráció). A területi differenciák elsősorban a településhierarchia mentén alakultak ki, s csak másodsorban az egyes régiók között. A foglalkozási szerkezet, a települések ipari-, agrár- és lakófunkcióiban mutatkozó különbségek mérséklődése, a mélyreható különbségekkel járó hierarchizálódás következménye volt, hogy a települések típusainak megállapításakor a hierarchikus szempontok kerülttek elötérbe. Ilyen szempontú volt az Országos Településhálózat-fejlesztési Koncepció kategóriarendszere, ha a tervezett állapotot vette is figyelembe.

- A városfejlödést - legalábbis deklaráltan - a településhálózat-tervezés irányította; 1971 óta az OTK. A reálfolyamatokra gyakorolt hatását különbözöképpen itélik meg. Mindenesetre ,ideológiai” hátteret adott ahhoz, hogy a településfejlesztés szélsőségesen „városorientált” legyen Magyarországon (hosszú időn keresztül a városoknak juttatva a településfejlesztési eszközök 90-92\%-át). Az OTK hozzájárult - ha nem is hozta létre, mint sokan vélik - a hierarchikus tagolódás túlzott szerepének kialakulásához, a városhálózat „modellszerüségéhez".

\section{A városfejlődés feltételei és eredményei 1990 után}

A városfejlődésnek ezek az általános feltételei változtak meg 1990 után:

- 1990 után fokozatosan kialakultak a piacgazdaság politikai, jogi, tulajdonosi feltételei. A települések, köztük a városok is kiléptek a települések „piacára". Ha nem is szünt meg - teljesen nem is szünhetett meg! - a településfejlödés lehetőségeinek „központi” befolyásolása (az önkormányzati fejlesztésimüködtetési eszközök igen magas hányada a központi költségvetésen keresztül jut el a településekhez, a saját bevételek aránya - néhány speciális helyzetú településtöl eltekintve - csekély stb.). Számos változás növelte a városok önrendel- 
kezésének lehetőségeit (az önkormányzat vagyonhoz jutása, az önkormányzati vagyonból származó bevételek, az önkormányzati jelleg erősödése, a privatizáció stb.). A gazdaság, de egyes városi intézmények telephelyválasztása is $a$ piaci verseny szabályai szerint zajlik, abba az állam (a kormányzat, a közigazgatás, a területfejlesztés szervei stb.) legfeljebb közvetett eszközökkel szólhat bele. A városok adottságai (földrajzi, forgalmi helyzete, a környezet állapota, az infrastrukturális ellátottság, a munkaerő-piaci helyzet, a vásárlóerő, a lakosság igényei, a városvezetés „nívója” stb.) határozták meg a gazdaság és - részben - az intézményhálózat mozgását.

- A gazdasági beruházásokhoz a korábbi gyakorlatban közvetlenül „,csatlakoztak" az infrastrukturális fejlesztések, az állami lakásépités stb. Ez a szoros kapcsolat mára megszünt, noha a „gazdaság” természetesen hozzájárul a foglalkoztatáshoz, a lakosság jövedelmeihez, a városok adóbevételeihez. Ám ezen kapcsolat lazulása korlátozza a területfejlesztés eszköztárát is. (Az iparfejlesztés és településfejlesztés korábbi szoros kapcsolata a múlté.)

- A piaci viszonyokat figyelembevevő gazdaság „mozgása”, telephelyválasztása új egyenlőtlenségek kialakulásához vezethet. A gazdaságfejlesztésnek ma nincs „szociálpolitikai” indítéka. Máris megindult a gazdaság regionális átrendeződése. A kedvezőbb adottságú térségek - Budapest, a fỏváros környéke, az Északnyugat-Dunántúl, a Balaton környezete stb. - tömörítik a gazdasági szervezetek többségét. Átalakulóban van az ország regionális szerkezete.

- Az 1990. évi önkormányzati törvény elfogadásával változtak a városfejlődés közigazgatási feltételei. Csökkentek az eltérő jogállásból fakadó elönyök és hátrányok. Az önkormányzati törvény nem tesz érdemi különbséget városok és községek között, csakúgy, mint a települések finanszírozási gyakorlata. Ez a tény „liberalizálta” a várossá-nyilvánítási gyakorlatot is. Ennek eredményeként ma már egy sor városi jogú település nem rendelkezik városi funkciókkal (Máriapócs, Ibrány, Nagyhalász, Pécel, Nyíradony, Téglás, Elek, Fertỏd, Felsözsolca, Izsák, Polgárdi stb.).

- Merőben új helyzetet teremtett a nagy hagyományú és hatalmú megyék szerepének drasztikus csökkentése. A megyék megszüntek hatalmi, pénzelosztó, területfejlesztési, közigazgatási egységként funkcionálni. Ugyanakkor az intézményszervezés ma is szinte kizárólag a megyék területi egységeit veszi figyelembe, nemegyszer indokolatlanul. Megyei keretekbe szervezödik, pl. a múzeumügy, a levéltári hálózat, az idegenforgalom hivatalos szférája, a közegészségügy, az igazságszolgáltatás, a könyvtárhálózat, a munkaügy, a statisztikai adatszolgáltatás stb. Így a megyeszékhelyek ma is kiemelkedő szerepet töltenek be a társadalmi élet szervezésében, a településhierarchiában, noha ez a szerep ma már jobban „megkérdőjelezhetö” a vetélytársak által, mint korábban. A megyék szerepe tovább csökkent azáltal, hogy a megyeszékhelyek s néhány nagyváros, mint Sopron, Nagykanizsa, Dunaújváros, Hódmezővásárhely, Baja ún. megyei jogú város, nem tartozik a megyék területéhez, illetve hatáskörébe, de még a nem megyei jogú városok fejlődésébe is kevésbé szólhat bele a megye- 
székhely, mint korábban, $\mathrm{s}$ így néhány hagyományos konfliktusforrás feloldódhat (Salgótarján-Balassagyarmat, Békéscsaba-Gyula, Zalaegerszeg-Nagykanizsa, Veszprém-Pápa stb.). Ez is a „szabadversenyes” városfejlödés lehetöségeit növeli.

- Az önkormányzati törvény megszüntette a jórásokat, illetve a helyưkbe lépett városkörnyékeket. A ,járási szint" kiiktatása a kisvárosi állományt fontos „fejlesztési tényezöjétöl", térszervezö szerepétöl fosztotta meg, annak ellenére, hogy számos városi intézmény ma is „regionális" hatáskörrel bír (bíróságok, ugyész-ségek, földhivatalok, rendör- és tüzoltó-parancsnokság, tisztiorvosi szolgálat, munkauigyi kőzpontok kirendeltségei stb.). Új hierarchizáló elem lehet viszont a kőzigazgatási régiók és központjaik megjelenése a magyar közigazgatási terúleti beosztásban.

- Míg a tanácsrendszerben a központi finanszírozás, illetve a megyék szubjektív megítélés alapján határozták meg az egy-egy tanácsnak juttatott pénzeszkỏzöket, addig ma az önkormányzatok normatt́v központi ellátásban részesülnek. (1986-ban már bevezették a normatív pénzelosztás egyes elemeit; a megyék ily alapon részesulltek a központi költségvetés juttatásaiból, viszont ơnálloan dőntöttek a „továbbosztás” elveiroỏl.) A költségvetési juttatásokat részben az egy före juttatott fejkvóták, részben meghatározott feladatok kvótái (óvodai féróhelyek, iskolai tanulók száma, szociális ellátásban részesullók száma stb.) alapján kapják az önkormányzatok, függetlenul jogállásuktól (város vagy község). Helyi adók kivetésére van lehetóségük az önkormányzatoknak, a központi adóztatás magas arányai miatt azonban a helyi adók kivetítésének lehetősége csekély. Így az önkormányzatok összes bevételeinek kétharmada a központi költségvetésból származik.

- Az „egyszintüvé" tett igazgatási-önkormányzati rendszer, a telepulések „egyenlösége" (a finanszírozási rendszerben, a települések jogaiban), a korábbi hatalmi kőzpontok (megyék, tanácsi székhelyek) kiiktatása korlátozta a „kưlsô” hierarchikus elemek szerepét a telepuléshálózat alakitásában, teret adott a piaci elemek hatásainak. Az önállóságon és egyenlöségen alapuló településközi integráció (társulás) ma még kialakulatlan. A spontán szerveződó kistérségek konfliktusba kerültek az 1996-ban jóváhagyott területfejlesztési tơrvény kistérség-szervezési elképzeléseivel. Így a kistérségek ma - még? - nem jelentenek városfejlesztó tényezöt.

- Novvelte a városfejlödés „szabadságát”, hogy a rendszerváltozás során érvényüket vesztették a korábbi terület- és településfejlesztési programok, s a tervezés, mint gazdaságirányítási eszköz majdnem teljesen eltünt a magyar gazdaságpolitikából. 1990 és 1996 közőtt ad hoc döntések alapján a hátrányos helyzetủ területek (aprófalvak, határmenti térségek) és a válságtérségek - ,jelentös munkanélkuliséggel sújtott térségek" - részesültek központi támogatásban. E célra hozták létre a Területfejlesztési Alapot. Az Alap rendelkezésére 1995-ben a magyar GDP 0,16\%-ának megfelelö összeg állt; az Alap sem mennyiségében, sem célrendszerében, sem elosztási rendszerében nem tudott megfelelni a terullet- 
fejlesztés új, a korábbinál sokkal nagyobb kihívásainak. Megállapitható, hogy az elmúlt években a tervszerü terület- és településhálózat-fejlesztés nem befolyásolta a településhálózat alakulását. Az 1996-ban jóváhagyott területfejlesztési és -rendezési törvény, valamint az időközben ugyancsak elfogadott Területfejlesztési Koncepció alapján megállapítható, hogy csökkent a települések szerepe a területfejlesztési elképzelésekben. (Az 1980-as évek végéig a terület- és településfejlesztés figyelmének középpontjában a településhálózat, illetve az egyes fejlesztési településkategóriák álltak.) Ez a szemléletváltás nem véletlen. Okai:

- Mind az „alulról építkező” területfejlesztési gyakorlat szerveződési egységei, mind a központi elképzelések, területfejlesztési akciók, programok címzettjei a térségek (kistérségek, megyék, régiók). A közvetett eszközökkel folytatott állami területfejlesztési akciók (pl. térségi infrastruktúrafejlesztés) hatása is térségi szinten mutatkozik (pl. autópálya-építés).

- A települések növekedése, összefüggésben az ország demográfiai helyzetével is, megszünt. A települések ,fejlődése" a piaci szféra, s néhány új funkció - pénzügyi központ, informatikai, vállalkozási központ, nemzetközi idegenforgalom stb. - térhódítása mellett olyan területeken nyilvánul meg, mint a városszerkezet átformálódása, a leromlott városrészek rehabilitációja, a városkép kedvezỏ irányú változása, a városi környezet értéknövekedése, infrastruktúra-fejlődés, a helyi társadalom ,polgárosodása”, a civil szféra térhódítása és így tovább. Ám ezek a szegmensek a területfejlesztés eszközeivel kevéssé befolyásolhatók.

- A telepulések ezen belsö fejlődése elsösorban a helyi önkormányzatok kompetenciájába tartozik.

- Nem a rendszerváltás következménye ugyan, de figyelembeveendỏ a városhálózat alakulásánál, hogy az csökkenö népességü országban zajlik, $\mathrm{s}$ ez a tendencia a népesség-előreszámítások szerint a jövő század elsỏ harmadában sem változik (az optimistább elörejelzés szerint 2040-ben 8,5-8,6 millió fó lesz az ország népessége). Az 1990-es évek elejére az ország valamennyi régiójában (megyéjében) természetes fogyás lépett fel. Ma már az ország tradicionális népességutánpótló teruleteinek (az Észak-Tiszántúlon Szabolcs-Szatmár-Bereg és HajdúBihar megye) és a korábbi bevándorlás révén fiatalos korösszetételủ megyék (Fejér, Komárom-Esztergom, Győr-Moson-Sopron) népesedési mérlege is veszteséges. A városhálózat mozgásfolyamatait tehát csökkenő népességszám, ennél is gyorsabban csökkenő aktív korú népesség mellett kell értékelni, ily körülmények között már a népességszám stagnálása is a dinamika jele, ugyanakkor az erőteljesebb migráció - aminek nincs jele -, egyes régiók vagy városok nagyobb arányú népességnövekedése az ország más területein súlyos népességvesztést eredményezne.

- A politikai-társadalmi változások kezdetben gazdasági recesszió közepette zajlottak. A gazdasági válságjelenségek részben az elmuilt évtizedek gazdaságpolitikájára vezethetők vissza, így az elavult gazdasági-ipari struktúrára, gyártmányszerkezetre, a gazdaság technológiai modernizációjának késésére, az 
„üzemen belüli" munkanélküliségre, a külfơldi adósságteherre, a verseny hiánya miatt elkényelmesedett vállalatokra és így tovább. Mások a politikai-geopolitikai-makrogazdasági váltás következményei, mint a KGST piac összeomlása, illetve a szervezet megszüntetése, a piacosodó viszonyok közepette nyilvánvalóvá váló gazdaságtalan, versenyképtelen termelés leállitása stb. 1989 után csökkent a bruttó hazai termék (GDP) értéke, ennél is nagyobb mértékben az iparban, kulönösen az építőiparban elóallított érték. 1988 és 1993 között az ipari keresők száma kb. 540 ezer fővel (az 1988. évi érték 38\%-ával), az összes foglalkoztatott száma 1,1 millióval csökkent. Az 1980. évi értékekhez viszonyitva 70-72\%-ra estek vissza a beruházások is, hosszabb távú, tartós recessziót jelezve.

- A termelés visszaesése - a közfelfogással ellentétben - nemcsak a bányászatra (1993-ban az 1985-ös termelés 57,6\%-át adta) és a kohászatra, fémfeldolgozásra (1993-ban az 1985-ös termelés 53,3\%-a) terjedt ki, hanem a korábban föleg KGST-piacra termelö ruházati iparra (a termelés 45,2\%-ra esett vissza 1985-höz képest), élelmiszeriparra (az export-értékesítés a korábbi [1985] 73,9\%-a) is. A termelés visszaesése egy sor bánya és ipari üzem bezárásához vezetett, föleg Borsod-Abaúj-Zemplén (szénbányák bezárása, az ózdi kohászat felszámolása), Nógrád és Komárom-Esztergom megyében. Mindezek következtében kiterjedt válságövezetek alakultak ki, melyek nemcsak a bányász- és ipari jellegú településeket foglalják magukba, hanem ingázási övezeteiket is. Nagy, összefüggő válságzónák alakultak ki Északkelet-Magyarországon, az Ózd-Miskolc tengely mentén, Szabolcs-Szatmár-Bereg megyében, Nógrádban, a Dunántúli-középhegység több bányászati körzetében. A termelés „látványos” visszaesése ugrásszerủen megnövelte a munkanélküliek számát.

- A válságtérségek kialakulása, a tömeges munkanélküliség jelentkezése máris kimutatható hatást gyakorol a településhálózatra. A válságövezetek városainak lélekszáma csökken (pl. 1990 és 1995 között Miskolc lakossága 14343 fövel [7,3\%], Kazincbarcikáé 2001 fỏvel [5,4\%], Ózdé 994 fövel [2,3\%], de 1980 óta 5868 [!] fővel, [12,1\%-kal] stb.). Átértékelödnek az ingatlanok, megváltoznak a települések kínálta elönyök és hátrányok. A kilencvenes évek derekáig - második feléig - tartó gazdasági recesszió nagymértékben differenciálta az egyes városok fejlődési lehetőségeit, általában lassította a településhálózat alkalmazkodását a megváltozott viszonyokhoz, illetve alaposan átrendezte az ország térszerkezetét. Feltehetó, hogy a meginduló gazdasági növekedés (amely azonban nem terjed ki az ország egészére, illetve jó néhány ágazatot nem érint) gyorsítja a városállomány átalakulási folyamatát, ugyanakkor növelheti a területi differenciákat.

- A rendszerváltozás óta megváltoztak a településfejlódés regionális keretei. Azok a változások, melyeknek egyes elemei már a nyolcvanas évek végén megjelentek (a magánvállalkozások növekvő súlya, a külföldi müködő tőke beáramlása, privatizáció stb.), majd a rendszerváltozás után felgyorsultak, mára már szembetünően átrajzolták az ország térszerkezetét, noha természetesen a folyamat még csak a kezdetén tart. Így az ország térszerkezete ma kiforratlan, gyorsan változik, visszaszoruló-megszünö és új elemeket egyaránt tartalmaz. 
Ezzel (is) magyarázható, hogy az ország makroszerkezetéról eltéró vélekedések alakultak ki a szakemberek körében is:

- A legáltalánosabb vélekedés szerint a Duna vonala jelent markáns határt a megújuló, kedvező helyzetü, csekély munkanélküliséggel sújtott, a „Nyugathoz" közelfekvő Dunántúl és a válság által leginkább érintett Alföld és Észak-Magyarország között.

- Elterjedt nézet az ország háromosztatú modellje; a Nyugat és Kelet elkủlönulése mellett hangsúlyozzák a föváros és a "vidék” éles elkülönülését, Budapest kiemelkedő jelentőségét a gazdaság „új” elemeinek befogadásában.

- Az empirikus vizsgálatok az elöbbieknél tagoltabb térszerkezetet tártak fel.

A térszerkezet átalakulásának föbb elemei a következők:

a) Korábban a településhierarchia mentén erős differenciálódás alakult ki, mind a társadalom összetételében, demográfiai jellemzöiben, mind a helyi munkaeröpiacon, az életkörülmények, az alapfokú ellátás stb. terén. Így a térszerkezetet a mozaikosság jellemezte. Ma ezen állapot inverziója figyelhetö meg: a kedvezỏ vagy kedvezötlen jelenségek térségi, regionális szinten jelentkeznek (megváltozó fơldrajzi fekvés, válságtérségek kialakulása stb.), a régiók között kialakuló differenciák lesznek a meghatározóak, ugyanakkor $a$ települések közötti differenciák mérséklódtek. A térszerkezet mozaikossága halványul, a regionális hovatartozás egyre szigorúbban határozza meg a települések lehetőségeit.

b) Változóban van a térségek, települések közötti különbségeket kialakitó tényezök fontossági sorrendje. Mig korábban a telepuléshierarchiában elfoglalt helyzet, az ehhez szorosan kötődő infrastrukturális ellátottság, intézményi ellátottság volt a legfontosabb differenciáló tényező, $s$ a teljes foglalkoztatottság keretei között a munkaerö-piaci helyzet kihatásai enyhébbek voltak, ma elsősorban a jövedelemszerzés lehetőségei határozzák meg egy-egy térség helyzetét (vállalkozások esélyei, munkaerő-piaci helyzet, a befektetők helyzetértékelése stb.).

c) A gyorsütemü változások következtében sokféle - lebomló és most alakuló, szervezödö - térszerkezeti elem „ell" egymás mellett; pl. a tradicionálisan hátrányos helyzetũ térségek, „újabb" válságtérségek, ahol a bányászat, kohászat és fémipar, hadiipar került válságba (,rozsdaövezetek”). Ezen térségekhez csatlakoznak a nagykiterjedésü - olykor megyényi - volt ingázási övezetek, ahol a munkanélküliség szélsőséges értékeket érhet el, a viharos gyorsasággal átértékelödó térségek (pl. az osztrák és szlovén határövezet, mely a „holt” határ idején forgalmi árnyékban fekvő, kedvezőtlen agráradottságú zóna volt, mára viszont kifejezetten elönyös helyzetủ területté vált, az osztrák piac közelsége, az ausztriai munkaalkalmak, a bevásárló-turizmus, a megélénkưlt idegenforgalom következtében stb.). 
d) A gazdaság, a szolgáltatások „új” elemei az átalakulás kezdeti szakaszában néhány térségben, településben, „hídfóállás-szerüen" jelennek meg. Ez, legalábbis átmenetileg, fokozza az egyes térségek, települések közötti (,színvonalbeli") különbségeket. Máig elsősorban Budapest és agglomerácioja, néhány régiókőzpont (Miskolc kivételével), s a nyugati határszél, a BécsSopron vagy Mosonmagyaróvár-Györ-Budapest tengely környéke dinamizálódott egyértelmüen. Így a térszerkezetben kitüntetett szerepet nyertek a pólusok.

e) Az ország nemzetközi környezetében végbemenő - gyors - változások igen rövid idön belül éreztették hatásukat a magyar régiók helyzetében. A határok "felnyitása", a politikai-gazdasági kapcsolatok irányának megváltozása az ország nyugati térségeit értékelte fel a keleti országrészekkel szemben. Hasonló hatással járt a keleti piacok összezsugorodása.

Az ország jelenlegi fejlettségi szint szerinti zónáit az 1. ábrán mutatjuk be. A fejlettségi szint megállapításánál elsősorban a gazdaságfejlődés 1990 utáni jelenségeit - beruházások, gazdasági szervezetek sürüsége, vállalkozói tevékenység, a külfooldi tőke jelenléte, munkaerö-piaci helyzet -, a munkanélkủliséget, a lakosság jövedelmi viszonyait stb. vettük figyelembe és nem a hátrányos helyzet hagyományos mutatóit, mint az alapfokú intézményellátottság, lakásfelszereltség, lakossági infrastruktúra, demográfiai helyzet és így tovább.

1) „Fejlett régió" Északnyugat-Magyarország és a budapesti agglomeráció; a budapesti agglomeráció mellett Györ-Moson-Sopron, Vas, Veszprém, Zala, Komárom-Esztergom megyéket, valamint Fejér megye északi felét foglalja magába. Vázát három dinamikus zóna, illetve magterület alkotja:

Budapest és agglomerációja. Területfejlesztési megfontolásokból négy évtizede folyamatosan megkísérelik fékezni a fôváros gazdaságának növekedését, csőkkenteni az országhoz mért súlyát, de az ,új” funkciók terén a föváros rendre visszaszerzi kiemelkedö helyét az országban. Ilyen funkció volt a hetvenes és nyolcvanas években a vállalatirányítás, a quaterner szektor, napjainkban a banki tevékenység, a külfoóldi befektetések, a kutatás-fejlesztés, a gazdasági szolgáltatások egyes fajtái és így tovább. Új jelenség, hogy a gazdaság dinamizmusa átlépte a föváros határait, $\mathrm{s}$ a korábban szélsőségesen egysíkú funkcióval (lakófunkció) rendelkezö agglomerációs övezetben is kiugróan magas a gazdasági szervezetek sủrúsége, a jövedelem, alacsony a munkanélkủliség, megélénkült az építési tevékenység, megjelentek a külföldi beruházók. Meglepỏen kedvező az ország legnagyobb üdülókörzetének, a Balaton környékének helyzete a statisztikai adatok alapján, mindenekelött a vállalkozói „sủrüség" terén. 

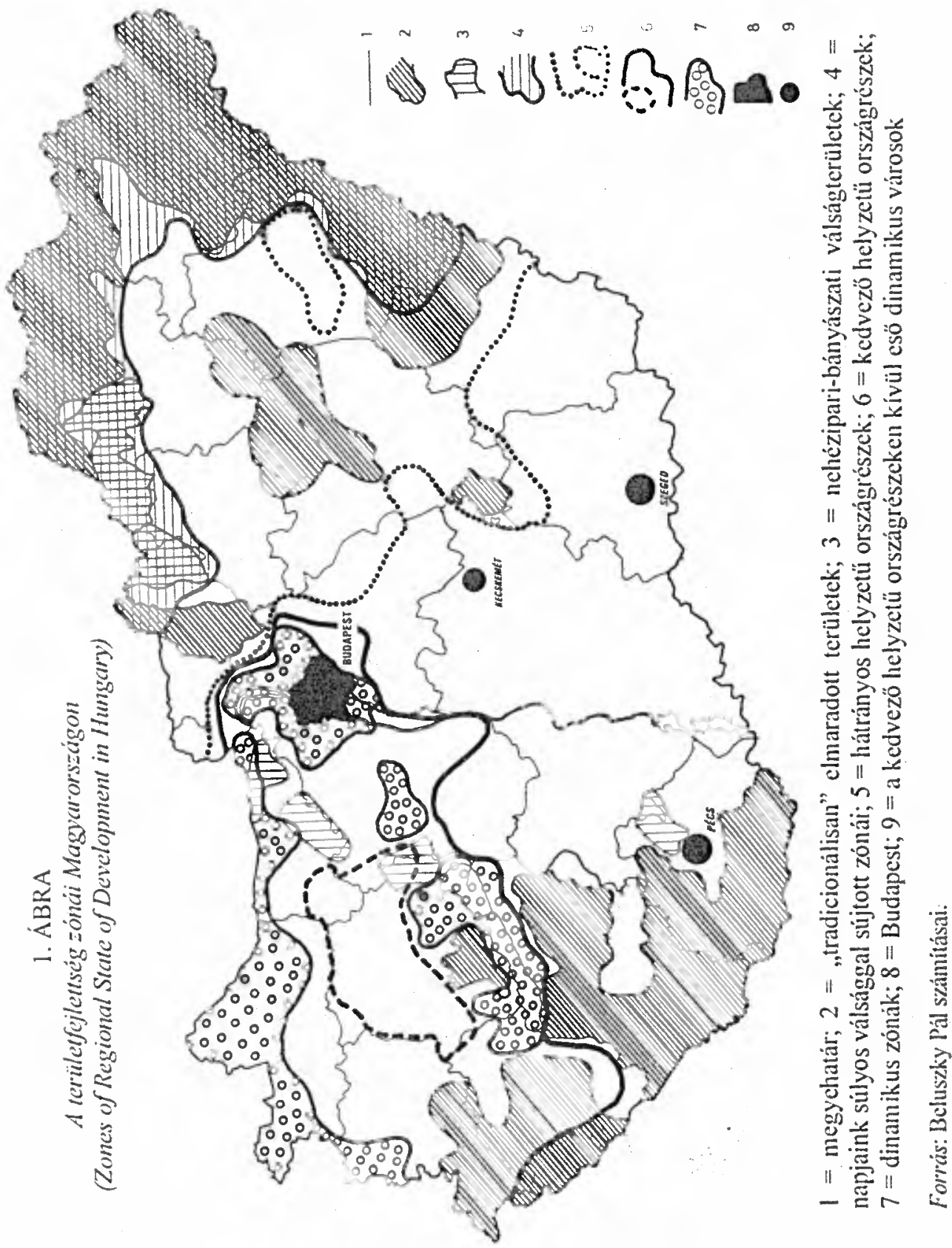
A prosperitás színterei ma még elsösorban a nagyobb városok, esetleg a speciólis helyzetü kisvárosok (a Balaton-part üdülővárosai, az Opel-müvek gyárának otthont adó Szentgotthárd, az idegenforgalmi jelentöségủ Köszeg, Sárvár stb.).

2) Északkelet-Magyarország; Nógrádtól Szolnok megyén keresztül Békés megye északi sávjában - a Szarvas-Gyomaendród-Békés-Sarkad vonalig - húzódik az ország válság sújtotta hátrányos helyzetú nagyrégiója. Magában foglalja Észak-Magyarországot (Nógrád, Heves, Borsod-Abaúj-Zemplén megyék), az egykori „energetikai-ipari tengely” keleti szárnyát. Ez a terület hosszú időn keresztül a gazdaságpolitika kedvezményezettje volt, magas beruházási értékekkel, állami nagyberuházásokkal, jelentős infrastrukturális beruházásokkal. Ugyanakkor az iparvidékek hátterében kiterjedt hátrányos helyzetủ - rosszul ellátott, infrastruktúra-hiányos aprófalvas térségek, nagyarányú elvándorlás, rossz adottságú, csak állami támogatással fenntartható mezögazdaság stb. - területek maradtak fenn, az iparvidékeken kívül fekvó területeket elhanyagolták, elmaradt az ipar mellett a további ágazatok - idegenforgalom, mezögazdaság, kultúra stb. - fejlesztése. De az állami mamutvállalatokon alapuló ipar rugalmassága, alkalmazkodóképessége is csekély volt, csakúgy, mint a „szervetlenül” fejlödö iparvárosoké. A gazdaságtalanná váló bányászat, a korszerütlen, rugalmatlan kohászati- és fémipar, a feleslegessé váló hadiipar általános válsága elsösorban ezt a vidéket sújtotta. Az üzemek bezárása, a termelés drasztikus visszaesése nemcsak a munkanélküliséget emelte megyei szinteken $20 \%$ köré, hanem a "monokultúrás" gazdasági-társadalmi élet minden szegmensét válságos helyzetbe hozta (pl. a régió oktatási intézményei is jórészt a nehézipar szakemberigényét kívánták kielégíteni). Felerősödtek a tradicionálisan hátrányos helyzetủ területek problémái (nagyarányú munkanélküliség, az agrárágazat válsága stb.). A térség városai sem mutatnak különösebb dinamikát.

3) Az Észak-Alföld (Szabolcs-Szatmár-Bereg megye, Hajdú-Bihar, Jász-NagykunSzolnok megye, Békés megye északi sávja) súlyos helyzetét több tényezö együttesen alakította ki: az 1960-as évekig egyveretủ agrártáj már a második világháború előtt kedvezótlen régiója volt az országnak. Noha az 1960 utáni iparosítás, a távolsági ingázás és a nagyarányú elvándorlás a foglalkoztatási gondokat mérsékelte, ennek ellenére nagykiterjedésü ,tradicionális" hátrányos helyzetü területek maradtak fenn. Kedvezötlenül változott meg az országrész földrajzi fekvése. Az térség korábban föleg KGST-piacokra termelö könnyü-és élelmiszeriparát épp úgy sújtja a kereslet hiánya, a termelés visszaesése, mint a bányászatot vagy a kohászatot. Az iparvidékek munkaerővonzásának nagyfokú csökkenése a távolsági ingázás lehetőségét szüntette meg. Az országrészt regionális kiterjedésủ munkanélküliség sújtja.

A foglalkozási szerkezet alapján az Észak-Alföld már nem tekinthetö agrártájnak, 1994-ben a keresők 12-13\%-a dolgozott a mezőgazdaságban. Ám a síksági jellegủ terület intenzív müvelés alatt áll, elsősorban szåntóként hasznosítják. A mezőgazdasághoz a lakosság sokkal jelentősebb hányada kapcsolódott, mint az agrárkeresőkre adódó 12-13\% (agrárkistermelés, kétlaki családok, 
kisegítő gazdaságok stb.). Így az agrárágazat súlyos válsága ugyancsak igen kedvezótlenül befolyásolta az Észak-Alföld helyzetét.

A különböző okokból kialakult hátrányos helyzetú térségek kiterjedt területeken átfedik egymást. Különösen kedvezőtlen a határmenti övezet (a Bodrogköz, Szatmár, Bereg, Bihar) helyzete, melyet épp a határmenti helyzet - a még ma is nehezen átjárható határok, a kedvezötlen forgalmi fekvés, a közép- és nagyvárosok hiánya - sújt, de a "tradicionális" területi hátrányok - kedvezötlen infrastruktúra, fejletlen települések, kedvezötlen jövedelmi viszonyok, kedvezötlen társadalmi mutatók - is általánosak, s ehhez járulnak az „új” válságjelenségek (igen rossz munkaerö-piaci helyzet, munkanélküliség, a vállalkozások csekély száma, alacsony jövedelemszint stb.).

4) Dél-Magyarország csak a fejlettségi szint szempontjából hasonló terület, de mind természeti viszonyai, mind gazdasági szerkezete, településhálózati jellemzői alapján eltérő régiókból tevődik össze. A Dél-Dunántúl (Baranya, Tolna, Somogy megyék, Fejér megye déli harmada) dombvidéki-síksági régiója korábban sem tartozott az ország fejlett országrészeihez, illetve a gazdaságitársadalmi fejlettség alapján eltérő kistérségekre tagolódott. Területének nagy részén a mezögazdaság adottságai közepesek vagy kedvezötlenek, az agrár árutermelés szerény volt, fontosabb átmenő útvonalak csak a régió peremét érintik, a közelmúltig városhiányos térség, a faluállomány túlnyomó többségét apró- és kisfalvak alkották. E kistérségek a „tradicionális” hátrányos helyzet térszínei voltak, s e jellegüket máig megtartották. 1989 után is ellentmondásosan alakult a régió helyzete: nincsenek olyan súlyos válságtérségei, mint Észak-Magyarországnak vagy a Tiszántúlnak, de a fellendülésnek sincsenek olyan jelei, mint az Észak-Dunántúlon vagy a fơvárosban és környékén. Nem vonzza a külföldi tókét, alig termel exportra.

A Dél-Alföld a Duna-Tisza közét és a Dél-Tiszántúlt foglalja magában. Az országrész mezögazdaságában hagyományosan fontos szerepe volt a speciális kultúráknak, az árutermelésnek, a hagyományos paraszti termelés mellett az agrárvállalkozásoknak. E specializált termelés mára még sokszínübbé vált. Piacaikat is jórészt megtartották (ebben szerepe van annak is, hogy élelmiszeripari üzemeik egy részét nyugati cégek vásárolták meg), az agrárágazatban élénk vállalkozói tevékenység folyik. A gazdasági szervezetek sürüsége általában is magas. A Dél-Alföld ipara igen változatos volt, a termelés visszaesése mérsékeltebb. A kistérségek fejlettsége többnyire közepes, a nagyobb városoké (Szeged, Kecskemét, Békéscsaba, Baja, Hódmezövásárhely) az átlagosnál jobb. A régióban így mutatkoznak „kitörési pontok”, s a gazdasági színvonal emelkedése szoros kapcsolatban áll(hat) a településhálózat adottságaival (1. ábra). 


\section{A városállomány átalakulásának eredményei}

A megváltozott feltételek - noha a telepủléshálózat meglehetősen lassan reagáló rendszer - már a napjainkig eltelt évtizedben is érzékelhető változásokat eredményeztek.

A városoknak a településhálózatban betöltött szerepére legközvetlenebbül a (város) hierarchiában elfoglalt pozíció utal. A települések között kimutatható hierarchikus tagolódás, a városok hierarchikus „szintje” (központosultsága) a városi alapfunkciók mennyiségétôl és minőségi kombináciỏjától függ. A városi alapfunkciók kőzé a tágabban értelmezett szolgáltatási ágak nem mindennapos igényeket kielégítơ intézményei, illetve tevékenysége sorolódik. Napjaink városhálózatát a 2. ábrán mutatjuk be (a hierarchikus beosztás elkészitéséhez 174 mutatót használtunk fel). A városhierarchia hosszabb távú változásairól megállapítható:

- Jelentősen javítottak pozícióikon a budapesti agglomeráció városai. Szentendre a hatvanas években a rangsor századik helye körül található, hiányos funkciójú kisváros, mára viszont a középvárosok közé került s egy sor megyei intézménnyel rendelkezik. Érd, Budaörs, Százhalombatta, Szigetszentmiklós, Dunakeszi szinte a „semmibỏl”' lépett elö kisvárosi központi szerepkörrel rendelkező településsé. Városi funkcióik mennyisége is esetenként tekintélyes. Elókelö helyezéseik ellenére városi funkcióik kiegyensúlyozatlanok - egyik említett városban sem múkődik, pl. kórház -, elöretörésủket elsősorban a magánszféra (kereskedelmi, idegenforgalmi, pénzügyi szolgáltatások) gyors gyarapodásának köszönhetik.

- Egy sor üdülőhely-fürdőhely nyert városi rangot az elmúlt években, ezek közül többnek városi szerepköre is bỏvült; Balatonboglár, Fonyód, Balatonalmádi kisvárossá lépett eló, de javított helyezésén Siófok, Balatonfüred, Balatonlelle is. E városok központi funkciói is sajátosak: egyrészt egyoldalúak (Siófokot és részben Balatonfưredet nem számítva), az idegenforgalommal kapcsolatos ágakban kiemelkedók, másrészt nagyarányú évszakos pulzáció jellemzi azokat.

- A regionális helyzetben bekövetkezett változások eredményeként javultak Gyór és Sopron pozíciói. Győr közvetlenul Miskolc mögé zárkózott fel, a „,modern” funkciók terén egyenrangú a többi regionális centrummal - pl. Györ a legjelentősebb vidéki pénzintézeti kőzpont -, az államilag telepített funkciók terén viszont megmaradt hátránya ( $\mathrm{pl}$. az egyetemi és fơiskolai oktatás terén).

Sopron rangszáma is csak keveset emelkedett, viszont egyetlen nem megyeszékhelyként bekerủlt a megyeközpontok sorába, szintén a magánszféra által uralt funkciók - idegenforgalom, kereskedelem, magánorvosi tevékenység, gazdasági szolgáltatások, pénzintézeti szolgáltatások stb. - jóvoltából. 

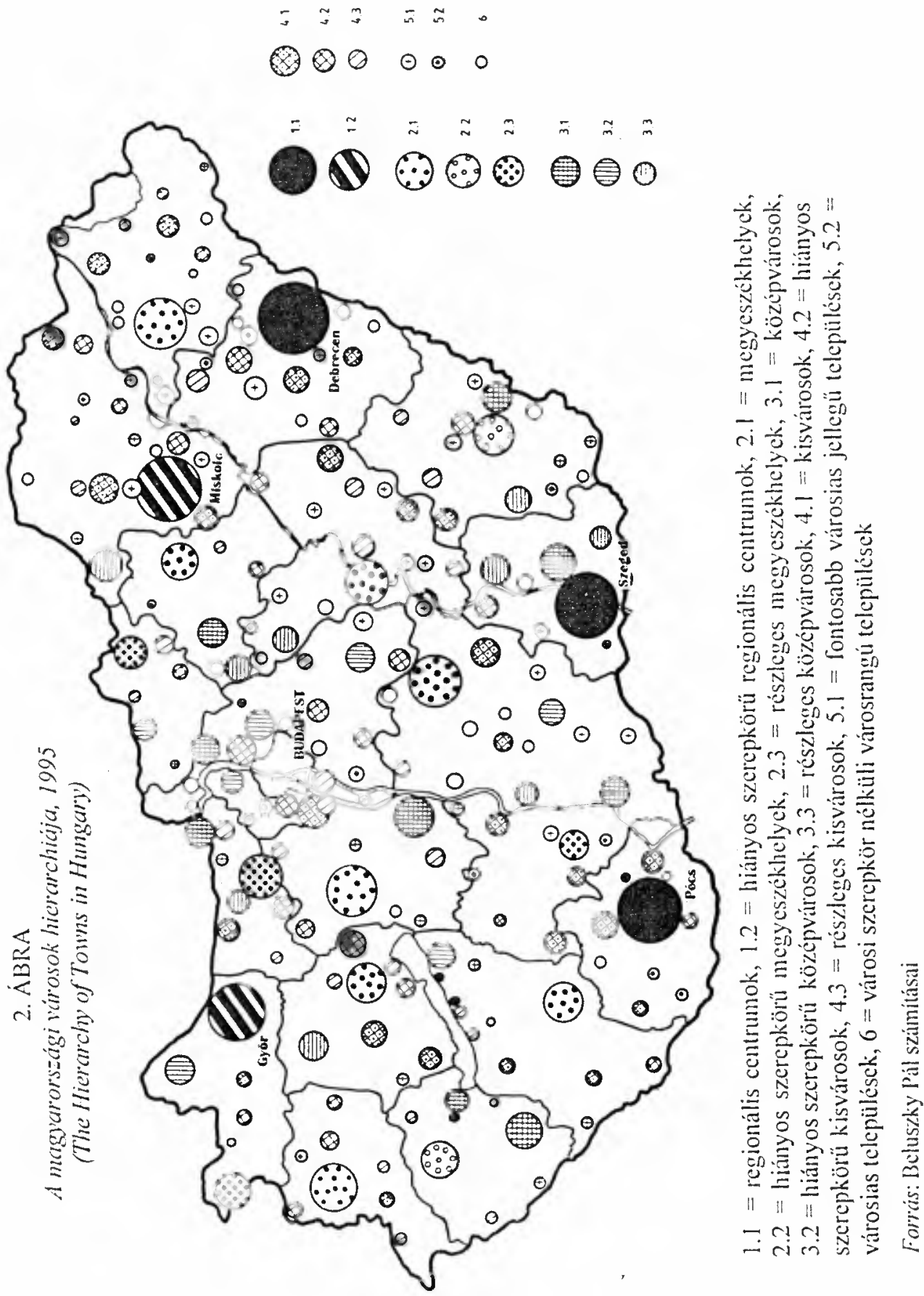
Györ és Sopron esetében tehát megfigyelhető az elmúlt évtized városfejlödésének egyik új aspektusa: a "hivatalos”, ,felülröl irányitott" településfejlesztéstôl elválhat a magánvállalkozások, illetve a tisztán piaci alapon szervezódó intézmények által kiváltott településfejlödés. Ennek észlelése, illetve a két különböző „sikon” folyó fejlődés-fejlesztés összehangolása a sikeres terület- és településfejlesztés fontos feltétele.

- Hosszabb időszakot figyelembe véve javítottak pozícióikon az ún. szocialista városok is, ez az elöretörés azonban föleg a hatvanas-hetvenes évekre tehető. Az elmúlt években viszont súlyos strukturális gondokkal küzdöttek, az „új”" funkciók megszerzésében nem sikeresek (Ajka, Kazincbarcika, Tiszaújváros, Oroszlány, Százhalombatta); ugyanakkor az iparvárosok többsége integrálódott a településhálózatba, magas hierarchikus helyezést ért el; Dunaủjváros és Ózd (még?) középváros, Kazincbarcika, Ajka, Komló, Várpalota stabil kisvárosok, városi funkcióik mennyiségi mutatói is igazolják számottevő városi szerepkörüket.

- Szerényebb pozícióba került egy sor olyan tradicionális középváros, amely az elmúlt évtizedekben nem tett szert új funkciókra, s hagyományos piacközponti, kisipari, illetve szolgáltató funkcióik is kisvárosi szintre estek vissza (pl. Mohács, Kiskunfélegyháza, Sátoraljaújhely, Karcag, Nagykőrös, Komárom, Kisvárda, Mátészalka stb.).

- Ugyancsak vesztettek hierarchikus rangjukból azok a korábban kisvárosi szerepkört betöltó járási székhelyek, melyek közigazgatási szerepüket a hatvanas-hetvenes években elvesztették, $s$ azt más téren - pl. ipar, idegenforgalom stb. - nem tudták pótolni. Ezek tơbbségét az elmúlt évek várossá nyilvánításai „rehabilitálták” ugyan, de korábbi rangjuk visszaszerzésére kevés esélyük van (pl. Tab, Jászapáti, Szikszó, Mezőcsát, Tiszalök, Putnok, Nagykálló stb.).

A vázolt változások ellenére az elmúlt évtized csak csekély mértékben alakította át a magyarországi városok hierarchikus rendjét. Változatlan a regionális centrumok köre, közủlük továbbra is három város tölti be maradéktalanul ezt a szerepkört: Szeged, Debrecen és Pécs. Némiképp változott Györ pozíciója. A város a századfordulón nem töltött be regionális szerepkört. A Dunántúl északnyugati felén nem is alakult ki országrész-központ. Néhány ilyen funkciót Györ, Sopron, Szombathely egyaránt ellátott. Trianon után kezdett Györ regionális szerepkört kialakitani, ehhez azonban kevés állami segítséget kapott, csakúgy, mint 1945 után. Szerény helyet foglal el a vidéki felsőoktatási központok sorában, nem vált regionális egészségügyi centrummá stb. Az utóbbi évek során azonban a legjelentősebb vidéki pénzintézeti, vállalkozási, kereskedelmi központtá emelkedett, gyarapodott idegenforgalma, gazdasági szolgáltató ágazata stb. Ezen funkciók révén $G y o ̋ r r$ felzárkózott a tơbbi regionális centrum mögé, miközben a piaci szféra hierarchiájában s az államiönkormányzati intézmények hierarchiájában elfoglalt helyzete távolodik egymástól. Miskolc több évtizedes kedvezményezett helyzete ellenére sem tette egyértelmúvé 
helyét a legmagasabb hierarchia-osztályban, még városi funkciónak mennyisége is elmarad a három vezetỏ regionális centrumétól.

Az EU-csatlakozás és a várható városfejlödés kérdéséhez szorosan kapcsolódik a regionális centrumok, a régió-székhelyek és a-jórészt EU-ösztönzésre és csatlakozási feltételként kialakítandó - (igazgatási-fejlesztési) régiók összefuggéseinek kérdése. A dolgok jelen állása szerint hét régió kerülne kialakításra (3. ábra). A valós térszerkezeti egységek és régióközpontok, illetve a vélhetö régió-székhelyek közt jó megfelelés mutatkozik az Észak-Alföld esetében.

Debrecen regionális vonzása a trianoni határmegvonás elött az ÉszakkeletAlföldre (Szabolcs-Szatmár, Bereg, Ugocsa, Ung, Hajdú megyék, az Érmellék) s az azt övezó hegységkeretre terjedt ki, vallási, oktatási, illetve kulturális téren a Nagykunságra is. Jelenleg regionális funkcióinak vonzáskörzete egyértelmüen „lefedi” a Tiszántúl két északi megyéjét, valamint a Nagykunságot és Tiszafüred környékét; szoros kapcsolatokat tart fenn a zempléni területekkel, felsőoktatási intézményeinek, klinikájának vonzása kiterjed Borsodra és Abaújra, részben Heves és Békés megye határos részeire. Hasonló a viszony Szeged és a dél-alföldi régió, illetve Pécs és a dél-dunántúli régió esetében. Szeged magának tudhatja Csongrád és Békés megyét, Bács-Kiskun már erösen vonzódik Budapest felé, Baja környéke Pécs felé is, de a megye elsősorban mégis Szeged hinterlandjának számít. Pécs pozíciói is egyértelmüek Baranyában és Tolnában, Somogy megye nagyobbik részén, a Balaton-parti telepulések kapcsolata már szorosabb a fỏvárossal, mint a DélDunántúl föhelyével. Zala megye helyzete sajátos; noha a legtöbb regionális beosztásban a Dél-Dunántúl része, újabban bizonyos nyugat-magyarországi „identitástudat" is jelentkezik, amely Zala megyét Vas és Györ-Moson-Sopron társaságában helyezné el. Egyébként regionális kapcsolatainak többsége - már csak a közlekedési összeköttetések miatt is - Budapesthez köti a megyét. A pillanatnyi elképzelések szerint ez a három megye (Zala, Vas, Györ-Moson-Sopron) alkotna egy régiót; ekkor viszont - közlekedés-földrajzi megfontolások alapján - akár Szombathely régió-székhellyé választása is felmerullhet. A közép-dunántúli régióban jelenleg nincs regionális szerepkört betöltő város; lélekszáma, forgalmi helyzete okán minden bizonnyal Székesfehérvár tölthetné be ezt a szerepet. Miskolc és az északmagyarországi régió viszonya sem egyértelmủ. A város egyrészt csak hiányosan látja el a jelenleg regionálisnak tekintett funkciókat, másrészt a tervezett régió nyugati felével (Nógrád megye, Hatvan, Gyöngyös környéke) „természetes” kapcsolata alig van.

Ma még homogén és a hierarchián belul igen masszív csoportot képeznek a megyekőzpontok. Valamennyi - magasabb szintbe nem tartozó - megyeszékhely e kategóriába került, rajtuk kívül viszont csak egy város: Sopron. A megyék szerepe az 1990-ben hozott önkormányzati törvény szerint csőkkent. A megyeszékhelyeké kevéssé. 


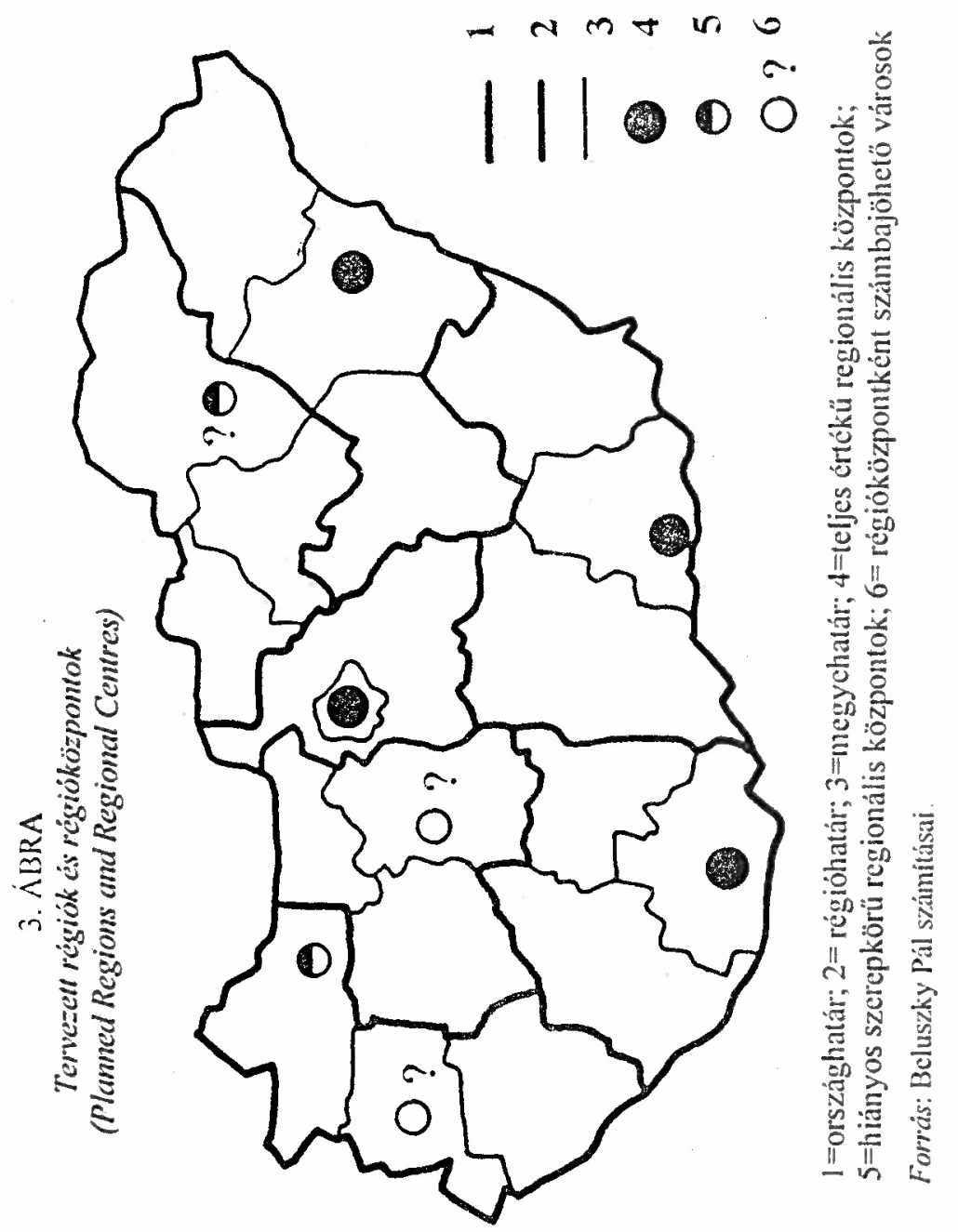


Az államigazgatás legtöbb ágazata ma is megyei keretek között müködteti regionális intézményeit (pl. munkaügyi központok, földhivatalok, statisztikai hivatal, tisztiorvosi szolgálat, adóhivatalok, rendőrkapitányságok, megyei közgyúlések stb.), csakúgy, mint az igazságszolgáltatás, s ezen intézmények székhelye kevés kivétellel a megyeszékhely. A korábban „államosított” társadalmi-gazdasági feladatok intézményrendszere ugyancsak megyei keretek között szervezödött, számos esetben különösebb indok nélkül. Ez a szisztéma máig keveset változott, $s$ a megyeszékhelyeknek eleve igen nagyszámú hivatalt és intézményt, köztisztviselői réteget, értelmiséget biztosít. Különösen a rendszerváltásig hatáskörük, hatalmuk is igen jelentős volt, további előnyökhöz juttatta a megyeközpontokat. Növeli szerepüket, hogy megszünvén a középszintü igazgatás, az állami hivatalok „keze” ma már csak a megyeszékhelyekig ér le. Máig csupán - s csak a legutóbbi évek eredményeként egyetlen nem megyeszékhely, Sopron tudott a megyeközpontok közé ékelödni.

A régiók kialakítása azonban feltehetően tovább csökkenti a megyeszékhelyek esetében az „automatizmusokat”, és felerösítheti közöttük - illetve a megyeszékhelyek és a fejlettebb kỏzépvárosok, mint Sopron, Nagykanizsa, Dunaújváros, Baja, Gyula stb. között - a városversenyt.

A városhierarchiát alakító szükebb értelemben vett városi funkciók mellett az elmúlt évtized változásainak felmérésére a városok "dinamikáját” is kimutattuk. A városok dinamikájának értelmezése több kérdést vet fel.

Természetesen a „dinamika” nem azonositható a növekedéssel, ugyanakkor a népességvesztés, az elvándorlás kétségtelenül munkaerö-piaci gondokat, kedvezötlen megélhetési lehetöségeket, a „karrier-lehetőségek” szükösségét is jelzi. Ettől eltér Budapest helyzete. Itt a népességcsökkenés részben abból fakad, hogy az elmúlt évtizedek adminisztratív korlátozásai nyomán a fövárosba való betelepedés visszafogott volt, a népesség elöregedett, s jelentős mérvủ a természetes fogyás. Másrészt a városból való „menekülés” - az agglomeráció olcsó övezeteibe való kitelepedés, visszaköltözés az előző lakóhelyre stb. - mellett felgyorsult az agglomeráció „elit” községeibe, kertvárosi negyedeibe, az új, kertes lakó-telepekre való kitelepedés. Ez valóban az urbanizálódás új szakaszát jelzi. A városok többségében a lakosságcsökkenéshez járul a munkahelyek számának csökkenése (ezen belül az ipari munkahelyek számának olykor zuhanásszerủ csökkenése), a munkanélküliség jelentkezése, a lanyha építkezési kedv és így tovább. E folyamatok a városállomány dinamikájának felmérésekor aligha hagyhatók figyelmen kivül.

Ugyanakkor az előbb említett folyamatok mellett - olykor azok ellenére - megjelennek a városokban a piacgazdaság városi intézményei, korszerüsödik a meglévő intézmények tevékenysége ( $\mathrm{pl}$. a bankoké); több-kevesebb dinamikával folyik a városok strukturális átalakulása. E minőségi változások közvetlenül többnyire nem mérhetők.

Vagyis a változások iránya, üteme, elörehaladása alapján két „sík” különíthető el, a hagyományos városi - többnyire állami - intézmények és a piacgazdaság intézményeinek síkja. Dinamikájuk gyakorta nem felel meg egymásnak. A mennyiségi 
elemek - népességszám-változás, a munkahelyek számának alakulása, lakásépítés, munkanélküliség stb. - döntő mértékben a hagyományos szerepkörökhöz kötődnek.

A városok dinamikai típusainak megállapítása egyszerủ módszerrel történt: a népességszám, a munkahelyek számának változásait, a munkanélküliségi rátát, a gazdasági szervezetek számának alakulását és a városhierarchiában bekövetkezett változásokat vettük figyelembe. A mutatókat öt-fokozatú skálán pontoztuk, a kapott pontértékek alapján szintén öt fokozatba soroltuk a városokat:

I. Dinamikusan fejlödö, növekvỏ városok

II. Mérsékelt dinamikájú városok

III. Stagnáló városok

IV. Pozícióikban visszaeső, stagnáló-hanyatló városok

V. Csökkenő méretủ, hanyatló városok

A vizsgálat eredményét a 4 . ábra tartalmazza. A rövidtávú tendenciákat figyelembevevó vizsgálat szerint a városok több, mint fele $(52 \%$-a) a két alsó kategóriába pozíciójukban visszaeső, stagnáló-hanyatló városok, illetve hanyatló, csökkenő méretủ városok - tartozik, a két felsổ kategóriába viszont alig több mint egyötödük. A városok funkcionális átformálódása (a piacgazdaság funkcióinak, hierarchiájảnak kialakulása) az elmúlt évtizedben recessziós folyamatok közepette folyt.

A városok dinamikai típusainak elterjedése országrészenként eltérő. A 12 dinamikusan fejlödö-növekvö város kivétel nélkül a Dunától nyugatra található, a budapesti agglomerációban (Szentendre, Budaörs, Érd, Szigetszentmiklós), illetve fürdỏvárosok-idegenforgalmi központok a Balaton partján (Siófok, Balatonalmádi, Balatonföldvár, Fonyód stb.), a Velencei-tó mellett (Gárdony), valamint Hévíz. Vagyis többségük kisnépességü, szerény városi funkciókkal rendelkező település. A múlté a megyeszékhelyek elszánt elöretörése, növekedése, noha többségük még szerényebb mértékben javította pozícióit. A Dunántúlon a városok kereken 70\%-a ơrzi vagy javítja helyzetét; a „hanyatló" városok közé a korábbi évtizedekben kialakult egyoldalú ipari városok (Komló, Várpalota, Oroszlány, Komárom, Nyergesújfalu, Tatabánya) és néhảny, a korábbi években mellözött kisváros (Vasvár, Zalaszentgrót, Dunaföldvár, Pécsvárad, Enying, a kisvárosok közé szerényült Mohács) került. Ez utóbbiak esetében nyilván a nyolcvanas évek figyelembevétele befolyásolta előnytelen besorolásukat. Az Alföldön viszont a pozícióikat javító regionális centrumok és megyeszékhelyek (Kecskemét, Szolnok, Nyíregyháza) s néhány speciális helyzetủ várostól (mint az idegenforgalmi szerepkört is betöltő Hajdúszoboszló, a régóta favorizált Záhony, az előnyös településhálózati helyzetú Baja) eltekintve általános a városok hanyatlása. 70\%-uk pozíciójából vesztő, hanyatló, csökkenö népességủ település. E városokat egyaránt sújtja a hatvanas-hetvenes években felduzzasztott iparuk termelésének drasztikus visszaesése (fỏleg a ruházati-, konzerv és élelmiszeripar), az agrárágazat válsága, a piacgazdaság városi funkcióinak vontatott terjedése „a Dunától keletre".

Csongrád megyében Szegedtől eltekintve csak ,dinamikátlan” városok találhatók; közéjük tartozik Csongrád, Hódmezóvásárhely, Szentes és Makó is (ez utóbbi funkció- és népességvesztése több évtizede tart). 

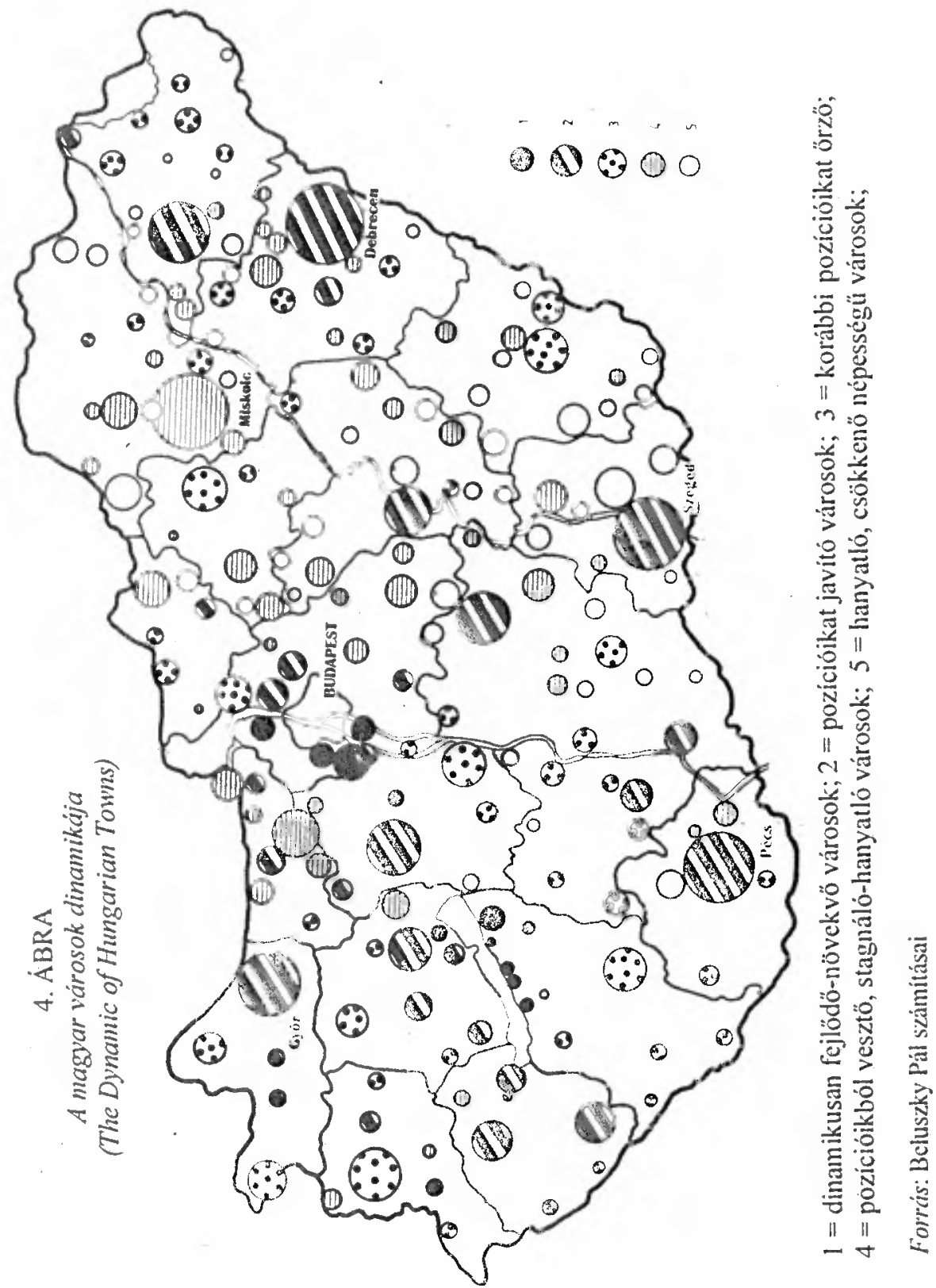
Békésben Gyula és Békéscsaba „tartja” magát, a többi tizenegy város „hanyatlik”. Hasonló a helyzet a Jászságban és a Nagykunságban is. Szabolcs-Szatmár-Beregben - tán a megkésett urbanizáció utolsó hullámaként - a városhálózat gerince, Mátészalka, Kisvárda, Nyirbátor, Fehérgyarmat, Vásárosnamény szintén örzi pozícióit. Észak-Magyarország súlyos depressziója a városok dinamikájában is tükröződik; még a regionális centrum szerepkörét betöltỏ Miskolc is pozícióiból vesztö, hanyatló város, csakúgy, mint a megyeszékhely Salgótarján, nem is beszélve $O ́ z d r o ́ l s$ a többi ipari városról (Kazincbarcika, Bátonyterenye, Sajószentpéter stb.). Feltünö, hogy az egyébként régóta hanyatló Hegyalja városai, Sátoraljaújhely, Sárospatak, Tokaj is a legrosszabb kategóriába kerültek.

Megállapitható, hogy az 1990 utáni változások egy része még a ,múltban" gyökerezik, az akkor folytatott településfejlesztésben, az akkor kialakitott gazdaság összeomlásában stb. Az is nyilvánvaló, hogy a városfejlödés feltételeiben 1990 táján alapvetô változások történtek, ám a bekövetkezett váitozások máig még nem mélyrehatóak. Kérdés, mennyiben változnak ezek a folyamatok az EU-hoz való csatlakozás következtében.

\section{Az EU-csatlakozás és a magyar városhálózat}

A magyar regionális fejlödés történetében a kilencveneses évek elején lezajlott rendszerváltozás új fejezetet nyitott. Eddig nálunk ismeretlen térformáló folyamatok jelentek meg, a rendszerváltozás egybeesett egy gazdasági szerkezetváltással és az önkormányzatiság felértékelődésével is. Nagyon gyors változásoknak lehettünk tanúi: a már korábban is stagnáló észak-magyarországi iparvidék összeomlásának, a nyugati területek felértékelódésének, az alfolldi agrárbázisú gazdaság piacvesztésének és a föváros minden tényezó tekintetében páratlan kiugrásának. Ezek a folyamatok jellegadóan befolyásolták a városok fejlödését is. A városhálózat bonyolult képződmény, természetéböl következik, hogy lassan változik, a rendszerváltás kora azonban itt is meghatározó változásokat hozott. Úgy tủnik, hogy az átrendezỏdés nagyon gyorsan lezajlott a kilencvenes évek elején, azóta a mozgások üteme jóval lassabb, egyes kutatók a térszerkezet megmerevedéséröl beszélnek (Nemes Nagy 1996). Annyi bizonyos, hogy egy-két évtizedre az ekkor kialakult kép jellemzi, és fogja jellemezni hazánkat, amit nagyon leegyszerüsítve nyugat-kelet kettősségnek hívunk. Ez a kettősség valójában inkább mozaikosság, mind nyugaton találhatunk belső perifériákat és hátrányos helyzetủ területeket, mind az ország keleti részén elöbukkannak a dinamikus városi centrumok (Enyedi 1996).

Magyarországnak - reményeink szerint hamarosan - ujabb változás elé kell néznie, olyan változás elé, amely hosszú idöre meghatározhatja hazánk jövőjét. Az Európai Unióhoz való csatlakozásunk - amelyet optimista becslések 2002-re tesznek - ismét új tényezöket jelent majd a regionális fejlödésben. A kérdés az, hogy ezek az új tényezők mennyiben rajzolják át a mai képet, teljesen új festmény kerekedik-e belóle, vagy csak hangsúlyosabbá válnak a mai tónusok, esetleg fontos új vonalak (színfoltok) is felkerülnek a vászonra. Mindezeket a kérdéseket feltehetjük 
a magyar városhálózattal kapcsolatban is: hogyan alakul (át) az EU-csatlakozás hatására városrendszerünk.

Vizsgálódásunkat megkönnyíti, hogy nemzetközi összehasonlítást készíthetünk; mi történt hozzánk hasonló helyzetủ országokban, amikor csatlakoztak az EU-hoz. Hozzánk hasonló helyzetü, azaz az Európai Unió magterületeinél fejletlenebb, periférikus fekvésủ, szegényebb államokról van szó. Írország, Görögország, Spanyolország és Portugália azok az országok, amelyeket vizsgálhatunk. Írországot találtuk olyan országnak, amely különösen alkalmas az összevetésre, itt ugyanis a hatvanas években adták fel a protekcionista, importhelyettesitö gazdaságpolitikát, és csak 1973-ban csatlakoztak az Európai Közösséghez. Tehát a gazdasági „rendszerváltást" bỏ évtizedes távolsággal követte a csatlakozás. Reményeink szerint hazánkban is ez következik be. Írország GDP-je ekkor az EK átlagának 45,6\%-a volt (Horváth 1997a), ma a magyar GDP az EU átlagának harmada körül van. Az összehasonlításnak azonban nehézségei is vannak: a világgazdaság képe ma egészen más, mint a hatvanas években vagy a hetvenes évek elején volt, azonkivül az EU is jelentös fejlödésen ment át. Mindezen akadályok ellenére az összevetésböl értékelhetö tanulságok is leszürhetök.

Írország térszerkezetét a hatvanas évekig az iparosodottabb keleti területek (a külföldi cégek közül szinte kizárólag angol vállalatok jelenléte), és a rurális, fejletlen nyugati területek kettőssége jellemezte. A hatvanas évek elejétöl telepedtek meg az országban a fejlett technológiát hozó (gyógyszergyártás, elektronika) külföldi vállalatok. A külföldi tőke elsősorban az elmaradottabb területeket preferálta, kedvező hatásuk is elsősorban itt jelentkezett. Ebben az időszakban a hagyományos iparágakkal jellemezhetö keleti körzet hanyatlásnak indult, a külföldi tőke is elkerülte ezeket a depresszió sújtotta vidékeket. A telepítö tényezö elsősorban az alacsonyabb bérek elönye volt, nem igényeltek helyi beszállítókat, ezért is maradt kisebb jelentőségủ az ország hagyományos ipari körzete. Az EK-hoz történő csatlakozás után új befektetők jelentek meg, elsősorban a Közösségen kívülröl, akik Írországot ugródeszkának használták, hogy az EK védett piacaira betörhessenek. Ök is a korábbi külföldi vállalatokhoz hasonlóan a nyugati országrészt részesítették előnyben, ök sem a helyi fogyasztópiacra telepultek, nem volt szerves kapcsolatuk a honi gazdasággal ( $O^{\prime}$ Malley 1997). Ebben az általános kiegyenlítódési folyamatban (amely természetesen nem lehetett tökéletes, a keleti országrész máig fejlettebb maradt), a településhierarchia is sajátos tagolódási tényezöt jelentett. Már a hatvanas évektöl a kisvárosok lettek a kedvelt telepítési helyek, a feldolgozóipar a hierarchia alsó szintjeire települt, a magas munkanélküliségi ráták sem itt, hanem a nagyvárosokban alakultak ki (Barry 1997). A Közösség által különbözö alapokból nyújtott támogatásból Írország egész területe (mint egyetlen régió) részesedett. Elméletileg nagyobb hányadot élvezett ezekből az elmaradott nyugati térség, ez a mezőgazdasági és az ipari jövedelmek nivellálódásához vezetett, azonban az igazi haszonélvezöje a keleti, délkeleti térség lett. A támogatások csökkenésekor a nyugat sínylette meg inkább a forráskiesést (Horváth 1997a). 
Írország analógiája alapján egy nagyon fontos következtetést vonhatunk le: az ország térszerkezetében a döntő változást nem az Európai Közősséghez való csatlakozás jelentette, hanem a külgazdasági nyitás; a csatlakozás csupán árnyalni tudta a korábban megjelent képet. Az EK csatlakozás után a befektetők ugyanazokat a területeket részesítették elönyben, mint a korábban érkezettek, a területi kiegyenlítést célzó politika pedig nem tudta eredeti célját elérni.

Magyarország EU-csatlakozása után különböző alapokból (Kohéziós Alap, Regionális Fejlesztési Alap stb.) jelenös támogatás érkezik országunkba. Ezekből a támogatásokból a regionális fejlesztés törvényeinek megfelelően elsősorban a fejletlenebb területeknek kell részesedniük. Az EU nézőpontjából gyakorlatilag Magyarország egész területe ilyennek minősül, mivel Budapest GDP-je sem éri el az Unió átlagának $75 \%$-át. Az EU gyakorlata alapján a problematikus térségek között a támogatás megoszlása viszonylag egyenletes! Nálunk az északkeleti megyék politikai okokból is demográfiai súlyuknál aránytalanul nagyobb támogatásban részesültek (Horváth 1997b). Az EU támogatások megszerzéséhez szükséges társfinanszírozási rendszer müködtetése, elsősorban önkormányzati, lakossági források bevonása. Központi támogatásra a települések ugyanis csak országos célú pályázat esetén számíthatnak. A társfinanszírozás megvalósulásához növelni kell az önkormányzatok pénzügyi önállóságát, elsősorban helyi adókra támaszkodva. A társfinanszírozás egyéb hátrányaival is számolnunk kell (Horváth 1997b). Amely programokra uniós támogatás érkezik, oda kell fordítanunk a nemzeti forrásokat is, így egyáltalán nem biztos, hogy az általunk is preferált célok kapják a támogatást; mi több, a társfinanszírozás az éppen ide szánt hazai forrásokat is elvonhatja. Az érkezó támogatások célja elsősorban az infrastruktúra fejlesztése lesz, olyan gazdasági tevékenységet, amibỏl az EU piaca telített (ültetvényes növénykultúrák, állattenyésztés, textilipar) minden bizonnyal nem fognak támogatni (Horváth 1997b).

Ezek alapján elképzelhető, hogy az EU támogatások megléte nem jelenti azt, hogy radikális gyorsasággal sikerül majd csökkenteni a területi és településhálózati hátrányokat. A támogatások felhasználása bonyolult probléma. Gyakorlata mögött az a gondolat húzódik meg, hogy az egységes piac létrejötte egy országra - a verseny éleződése miatt - a regionális differenciálódás irányába hat. Ez nálunk már a világpiacba történő visszatérésünk során megmutatkozott. Az Európai Unióba való belépés után ez tovább erősödhet. A támogatások egyik célja tulajdonképpen az, hogy ezeket a káros hatásokat kompenzálja. A támogatási rendszer azonban nem múkődik tökéletesen, sok esetben minden kézzelfogható eredmény nélkül használják fel a rendelkezésre álló forrásokat. Az Európai Unióban némiképpen csökkentek a regionális különbségek, de nem a várakozásoknak megfelelö mértékben. Nem számolhatunk tehát azzal, hogy ezen pénzforrások segítségével rỏvid idỏ alatt gyökeres változáșíkat érhetünk el.

Sőt, egyes vélemények szerint ezeket a támogatásokat fokozott mértékben kell felhasználni a városokban, a nagyvárosokban. Részben ezt követelik meg az ország valós igényei, másrészt ezek a térségek tudják elôteremteni a társfinanszírozáshoz szúkséges összeget. Az európai regionális politika sem jelenti csupán a városkör- 
nyéki vidék fejlesztését. Úgy kell felhasználnunk a forrásokat, hogy eredményuik egy egységes szemléletü, összefogott ország-fejlesztés legyen, ha marad még eszköz, akkor kerülhet elötérbe a kiegyenlítés feladata. Mindezek összegzéseként: előfordulhat, hogy a relative fejlettebb területek jutnak nagyobb forráshoz. A településhálózatra vonatkoztatva ez azt jelenti, hogy a nagyobb városok, a koncentrált munkahelyteremtő térségi centrumok értékelödnek fel, s erösödnek meg (akár a támogatások hatására is) (Ruttkay 1998). Azt is számba kell vennuank, hogy a felülről jövő támogatások akkor érnek termékeny talajt, ha találkoznak a helyi adottságokkal, a meglévó tendenciákkal, a helyi társadalom törekvéseivel. Olyan városokban várhatjuk tehát a támogatások kedvezỏ hatását, ahol megvan az igény és a készség az innovációk fogadására, egyébként, mint feneketlen zsákban tünik el az odairányftott pénzek nagy része. A szocializmus utolsó évtizede szolgál példákkal arra, hogy a város a rendelkezésére álló állami pénzt kitúnően tudta felhasználni fejlesztése érdekében, az erre fogékony vezetỏ elitje révén. (Talán a legjobb példa Nyíregyháza lehet.) Ez az, amire most is szükség van, egy életképes városi társadalom, felkészült és invenciózus vezetö elittel, ez az a fogadóközeg, ami termékennyé teheti a támogatás akár szulik keretét is. A támogatások fölélése, esetleg szulkségtelen beruházásokba fektetése pedig konzerválhatja egyes városok hátrányos helyzetét.

Enyedi György 1996-ban megjelent könyvében a magyar regionális fejlődés három lehetséges forgatókönyvét vázolja. A három forgatókőnyv a gazdasági növekedés mértéke alapján három középtávú elörejelzést ad az ország regionális folyamatairól. Az elsỏ forgatókőnyv a gazdaság stagnálásával és a növekedés lassú megindulásával számol. Ez a lassú növekedés polarizált fejlődést vetítene előre. Ennek legszembetünőbb jele Budapest kiugrása a városhálózatból, nemzetközi nagyvárossá válása. A föváros nem funkcionális értelemben szakadna el hátországától, a gazdasági, társadalmi szálak továbbra is kötnék az országhoz, hanem dinamizmusa emelné ki az elsősorban stagnáló telepủlések kỏzül. Ez a fejlödési pálya Budapesten kívưl föleg a közép- és a nagyvárosokban jelzi elöre a gazdasági nővekedést, ezek közull is elsősorban a Dunántúlon, kitüntetetten a nyugati felén. A kisvárosok csoportjára és az alföldi városok többségére a stagnálás lenne jellemzö, lakosságuk lassú fogyatkozása felerősődne, az elvándorlás célterưlete a fơváros és agglomerációja, illetve a Nyugat-Dunántúl lenne. Az ipari depressziós térség városai sem tudnák megtartani népességưket, gazdaságuk elhúzódó válsága miatt. A második forgatókönyv a közepesen koncentrált fejlödés pályája lenne. Akkor következne be, ha a gazdasági növekedés folyamatos lenne, $\mathrm{s}$ az ezredforduló után fel is gyorsulna. Budapest kimagasló szerepét ez a forgatókönyv sem kérdőjelezi meg, Azonban ekkor nemcsak a nagyvárosokban stabilizálódna a gazdaság, hanem a középvárosokban is. A válságtérségekben is megjelennének dinamikus városi centrumok, amelyek kedvezöen hatnának környezetükre is. Az országon beluuli vándorlás kisebb mértékủ lenne, elsősorban egy régión belül mozogna a népesség. Felértékelödne a határmenti „kapuvárosok” szerepe. A harmadik forgatókőnyv megszakítatlan és felgyorsuló gazdasági növekedést feltételez, olyan szintüt, amely lehetővé teszi kőzéptávon az Európai Unió átlagának elérését. Ez lenne a dekoncentrált regionális 
fejlődés pályája. Itt is a budapesti agglomeráció lenne az ország legdinamikusabb terúlete, de ez a dinamizmus kiterjedne jóformán hazánk egész tertiletére, $\mathrm{s}$ a városhálózat egészére. A depressziós iparvidékekek városai újjáélednének, az Alföld városai is megközelítenék a Nyugat-Dunántúl városainak gazdasági élénkségét. A kedvező hatások folytán a kisvárosok szerepe felértékelődne, ez a településcsoport is dinamizálódna. Az országon belúli vándorlás liteme lelassulna, elkezdỏdne egyes teruleteken a falvak újranépesedése (Enyedi 1996).

A három fejlödési forgatókönyv más-más idópontra teszi Magyarország EU-csatlakozását. Az első forgatókönyv nem számol a közeljövőben csatlakozással, a másik kettő igen. Enyedi György elemzése óta eltelt idő azt a feltételezést engedi meg, hogy a második forgatókönyv leírása ad hủ képet hazánk jövőjéról. Ebbe a képbe közeli EU-csatlakozásunk is beletartozik. Ez a fejlödési pálya azt feltételezi, hogy a jelenlegi térszerkezeti felosztás lassan változna, a fejlettségi kưlönbség a nyugati régió és a fővárosi agglomeráció, illetve az Alföld, Észak-Magyarország és Dél-Dunántúl között csak lassan oldódna. Azonban a kettősség képe (a polarizált centrum-periféria modell) már semmiképpen nem lenne tartható (Nemes Nagy 1996). Felerősödik az ország térszerkezetének mozaikossága, a mindenütt elönyösebb helyzetben lévő közép- és nagyvárosi térségek kiugranak környezetükböl, kedvezó befolyást is gyakorolva rájuk. A kisvárosok csatlakozása ehhez az elökeló csoporthoz a Dunántúl nyugati részén várható, ez lesz a lényeges különbség kelet és nyugat között. Az innovációk, a külföldi tőke terjedését kétféle modellbe foglalhatjuk. Az egyik a hierarchikus terjedés modellje, a telepuléshálózat kitüntetett pontjai jelennek meg először (föváros, nagyvárosok) és lassan terjednek át a telepưléshálózat alacsonyabb szintjeire. A nagyvárosok előnyét kedvezỏ infrastruktúrájuk, sürübb kommunikációs hálózatuk is fokozza (Rechnitzer 1998a). A másik modell a diffúz terjedés modellje, amely ezek elterjedését szomszédsági kapcsolatokhoz köti, tényleges földrajzi közelséghez. Erre is jó példát szolgáltat Magyarország, a nyugati régió dinamikáját ezzel magyarázhatjuk. Ott bizonyult különösen élénknek a gazdaság fejlödése, ahol a két terjedéstípus találkozott egymással, erősítették egymást, tehát Nyugat- és Észak-Dunántúl nagy- és kőzépvárosaiban. A diffúz terjedés hatására még Vas és Győr-Moson-Sopron megye falvai is jelentösen átalakultak, a határhoz közelfekvő kisvárosokról nem is beszélve (Fertőd, Köszeg, Sárvár, Szentgotthárd). Ezen kétféle terjedéstípus felerősődésével, felgyorsulásával számolhatunk az uniós csatlakozás után, a gyorsítást nem utolsósorban a támogatások helyes felhasználása tenné lehetővé.

$\mathrm{Az}$ uniós csatlakozás után új fogalommal kell megismerkednunk: a városversennyel. Az egységes európai piacon a városok egymással is versengenek befektetökért, különböző támogatások elnyerésért. A városverseny különösen a hasonló adottságú, funkciójú városok között lesz éles. Vannak olyan helyi tényezők, amelyek rövid távú elơnyöket kínálnak: olcsó munkaerő, kedvezö adózási feltételek. Ezek a tényezök gyorsan változnak, a tőkemozgás is azonnal követi ezeket a változásokat és kedvezöbb befektetési terület után néz. Az erre épuliob gyors virágzást gyors hanyatlás válthatja fel. Tartós fejlődést kifejezetten helyspecifikus (unikális) 
adottságok indíthatnak el: nem is elsősorban az épített infrastruktúra (bár ennek szerepe [információ-gazdaság stb.] megkérdőjelezhetetlen), hanem egy innovációorientált, befogadásra kész társadalmi közeg (Enyedi 1996). Magyarországon a városverseny különösen éles lehet, mivel sok, hasonló adottságokkal rendelkező városunk van (pl. alföldi mezővárosok, hajdúvárosok). A verseny megléte mellett ezzel ellentétes jelenség is lejátszódik: az Európai Unióban egyre fontosabb szerephez jutnak a városcsoportok. Egyrészt egymáshoz földrajzilag közel lévő városok közötti funkciómegosztásra épülő csoportok ezek, másrészt egymástól távol fekvő, de hasonló adottságú, problémájú városok szövetségei. Támogatni és szorgalmazni kell ilyen városcsoportok létrejöttét, mindkét típusú szövetkezésre van lehetőség nálunk. A magyar városoknak is be kell kapcsolódniuk az európai városrendszerbe. Városaink nemzetközi, nemzeti és regionális jelentőségủ városok csoportjaiba sorolódnak, mindegyik más-más szerepkört, funkciót, más-más intézményrendszert jelent és kíván. Nemzetközi jelentőségú várossá válásra Budapestnek van egyedül esélye a magyar városok között. Nemzeti jelentőségű város pedig Győr, Székesfehérvár, Pécs, Szeged, Debrecen, Nyíregyháza és Miskolc lehet (Rechnitzer 1998b). Ezen utóbbi városok jelentősége azáltal is növekedni fog, hogy ők lesznek (Nyirregyházát leszámítva) a szerveződỏ régiók központjai. Ez már a közigazgatás decentralizációja miatt is számos új intézmény megtelepedését, esetleg a régiek bövülését vonja maga után. Nyíregyháza dinamizmusát és növekvő jelentőségét kitünö közlekedési fekvése magyarázza. Egyes megyeszékhelyek viszont éppen a régióközpontok javára történő funkcióvesztés miatt veszítenek jelenlegi szerepükből. Ez föként azokat a megyeszékhelyeket érintheti, amelyek pozíciója megyéjükön belül is gyengébb, s kitüntetett szerepüket központi funkciójuknak köszönhették (pl. Szekszárd, Zalaegerszeg esetleg Salgótarján). Az autonóm kistérségek azon központjai, amelyek jelentösége túlmutat körzetükön, megtartják vagy bỏvítik intézményeiket, a megye jelentőségvesztésével komolyabban konkurálhatnak a megyeszékhellyel. Ilyen városként jöhet szóba Baja, Nagykanizsa, Sopron, de akár Dombóvár vagy Mátészalka is.

A határ és a határmentiség az utóbbi időben egyre inkább felértékelödỏ kérdéssé vált az Európai Unióban. A határok átjárhatóságával megteremtődött a lehetőség a határokon átnyúló kapcsolatok, együttmüködések szélesítésére, s regionális együttmủködések kialakítására. Csatlakozásunk után kétféle országhatárral rendelkezik majd hazánk: az egyik, amely az EU-val köt össze minket, egy átjárható, laza határ (az osztrák, esetleg a szlovén, késỏbbiekben a horvát, a szlovák és a román határ), a másik típusú határ, amely elválaszt szomszédainktól (a jugoszláv és az ukrán határ távlatilag is ide sorolható). Mindkét határ speciális szerepet szán a határ mentén fekvő városainknak.

Azon határainkon, ahol nem EU tagországokkal érintkezünk, mi képviseljük majd az Unió keleti határát. Az itt lévő települések gateway-városokká (kapuvárosokká) válhatnak, ebben a szerepben fejlődésük új dimenziót kaphat. A kapuváros közvetíti a fejlettebb területekröl az innovációt, dinamizálja a szomszédos határvidékének gazdaságát, mintát ad és életstílust, kultúrát is közvetít. Erre a szerepre fel kell ké- 
szullni, nem csupán az infrastruktúra fejlesztésével, hanem a határon átnyúló kapcsolatok kiszélesítésével, regionális együttmüködések kezdeményezésével. Egyes vélemények szerint ezek a városok új fejlỏdési ,aranypatkót” alkotnak, Komáromtól Szentgotthárdig (Rechnitzer 1998b). Ezen városgyürủ elemei lennének: Nagykanizsa, Barcs, Siklós, Pécs, Mohács, Baja, Kiskunhalas, Szeged, Makó, Békéscsaba, Gyula, Debrecen, Mátészalka, Kisvárda, Nyíregyháza, Sátoraljaújhely, Miskolc, Salgótarján, Balassagyarmat, Esztergom. Ez az aranypatkó lehet az, amely a középeurópai térszerkezet jelenlegi fejlỏdési magterületét bỏvítheti. Ez a lehetőség az eddig periférikus fekvésủ Kelet-Magyarország városai számára biztosítana kitủnỏ kiugrási lehetőséget. Ezt a szerepet addig tölthetik be, amíg szomszédaink nem csatlakoznak az Unióhoz, erre azonban - úgy tủnik - nekik hosszabb ideig kell várniuk. Amennyiben csatlakozásuk megvalósul, akkor eurégiók alakítása és a teljes körú együttmủködés kiépülése szolgálhatja fejlödésüket.

Nemzetkői régió kialakítására a legesélyesebb terület Ausztria, Magyarország és Szlovákia érintkező zónája ${ }^{1}$. Ez a térség mindhárom ország legfejlettebb területeinek érintkezési pontja, történeti tradiciói alapján egységes tájegység volt valaha. A területen $m a$ is jelen vannak a három ország befektetöi által létrehozott vegyesvállalatok, személyes kapcsolatok hálója fonja egyre sürúbbé ezen terület szálait. A három ország nem egyenlő súllyal képviseltetné magát ezen régióban. A népesség 60\%-a Ausztriára esne, 30\%-a Szlovákiára, csupán 10\%-a Magyarországra. A régió városai is eltérỏ szerepkörủek: Bécs nemzeti fỏváros és nemzetközi nagyváros, Pozsony középvárosi mérete ellenére nemzeti föváros, míg Györ középváros és megyeszékhely. Mindezen különbségek ellenére is a jelen folyamatai (elsősorban Ausztria és Magyarország között) igazolják az itteni térszervezódés szervességét, és a tényleges adottságokban való gyökerezését. Szlovákia kedvező hangütésủ politikája, és jövőbeni EU-csatlakozása a záloga ezen nemzetközi régió formális létrejöttének (Enyedi 1996). Más területeken is van természetesen lehetöség ilyen egyưttmükődés kialakítására, azonban a feltételek korántsem ilyen kedvezöek (gondoljunk a Tisza-Kárpátok régió jelenlegi állapotára). Régiók közötti együttmüködésbe is bekapcsolódhatnak hazánk egyes területei, az Alpok-Adria Munkaközösségnek is tagjai magyarországi megyék.

A határok növekvő átjárhatósága mindenképpen hazánk alapvető érdeke. Egykor létező regionális kapcsolatok, melyeket a trianoni békeszerződés határmegvonása vágott ketté, ismét újjáéledhetnek, s ez nemcsak nekünk lenne kedvezö, hanem szomszédainknak is. Városok, amelyeket vonzáskörzetüktöl fosztott meg a békeszerződés, ismét nagyobb térségekre terjeszthetnék ki kedvezö hatásukat (pl. Sopron, Szeged, vagy a határ túloldalán Nagyvárad, Kassa). Vannak olyan elképzelések is, amelyek az egykori borostyánút tengelyében (lengyel, cseh, szlovák, magyar, szlovén területek észak-dél irányú kapcsolatában) látnak egy új gazdasági erőteret kibontakozni (Berényi-Dövényi 1996). Ez az elképzelés is csak akkor válhat valóra, ha ezen országok hazánkhoz hasonlóan az Unió tagjai lesznek. 
Vannak olyan városaink, amelyek jelentősége a csatlakozás során mindenképpen felértékelödik, ezek az idegenforgalomra specializált városok. Ezek a városok kevésbé koncentráltan helyezkednek el az ország területén, kedvezỏ hatásuk is nagyobb térséget érinthet. A ma meglévő ilyen adottságú településekhez (Balatonkörnyék, gyógyfürdö városok: kitüntetetten Siófok, Keszthely, Balatonfüred, Hévíz, Harkány, Bükk, Hajdúszoboszló) a jövőben továbbiak fognak csatlakozni: az Unióban reneszánszát élő ökoturizmus potenciális területei. Ez természetesen nemcsak városokat érinthet, de a kedvezỏ hatások jórésze ezen területek központjaiban fog megjelenni. Az Alföld városai közull is bekapcsolódhat néhány ezek közé (pl. Balmazújváros, Tiszafüred). Ez sem érhet minket készületlenül, elsősorban infrastruktúra-fejlesztéssel kell várnunk a vendégek bỏvülő körét, erre uniós támogatást is szerezhetünk.

Összegzésül azt mondhatjuk, hogy uniós csatlakozásunk rövid távon csak árnyalni fogja a kilencvenes évek elején kialakult térszerkezetet. A csatlakozás utáni elsó időszakban még mindenképpen a meglévő területi különbségek növekedésével számolhatunk. A kedvező hatások hosszabb távon fognak jelentkezni. Ez jelenti majd a kiegyenlítỏdés megindulását, olyan területek dinamizálódását, amelyek ma depressziós vagy tradicionálisan elmaradott területnek számítanak. A városhálózat tekintetében a kiegyenlítődés azt jelenti, hogy a ma gazdaságilag stagnáló kis- és középvárosok is kedvező befektetési területté válnak, gazdaságuk stabilizálódik, megélénkül, népességvesztésuuk megáll. Mindez érvényes a válságterületek városaira is, ezen területeken a kedvezö változások elindítói a városok lehetnek. Azzal is számolnunk kell azonban, hogy lesznek olyan térségek és települések, amelyek nem tudnak bekapcsolódni a kedvezỏ folyamatokba. Ezeken a helyeken érzékeny és hatékony szociálpolitikával kell elejét vennünk az életszínvonal süllyedésének.

Az Európai Unióhoz való csatlakozásra minden területen fel kell készülnünk. Elsősorban intézményhálózatunkat kell európai arculatúra formálnunk, fel kell készülnünk a támogatások eredményes pályázására. Spanyolország nagy elókészületei ellenére évekig nem volt képes a rendelkezésére álló keretösszeget sikertelen pályázatai miatt felhasználni (Ruttkay 1995). Nem szabad azonban a támogatásokat fetisizálnunk, ezek a támogatások csak akkor érik el céljukat, ha megfelelóen használjuk fel öket. Tudnunk kell, hogy az EU csatlakozásnak csak egyik vetülete a hozzánk érkezö támogatás, sokkal fontosabbak azok a hatások, amelyek gazdaságunkat, esetünkben településhálózatunkat más irányból érik.

\section{Jegyzet}

' A kézirat leadása óta Burgenland, Győr-Moson-Sopron és Vas megye egyuuttmükỏdésével 1998. október 1-jével megalakult a Nyugat-Pannonia Eurégió, melyhez azóta Zala megye is csatlakozott. 


\section{Irodalom}

Barry, B. (1997) Írország modernkori iparositása. - Regionális átalakulás a Brit-szigeteken. - Horváth Gy. (szerk.), Pécs, MTA RKK.

Beluszky P. (1990) Magyarország városhálózata 1900-ban. Tér-idõ-társadalom. - Tóth J. (szerk.), Pécs, MTA RKK.

Beluszky P. (1996) Kompország városai (Történeti régiók és városok). - Tér és Társadalom. 1. 23-41. o.

Beluszky P. (1967) A magyar városok kőzponti szerepkőre. - Statisztikai Szemle. 6. 543-563. o

Beluszky P. (1998) A polgárosodás tơrékeny hídfơi (Magyarország városainak ezer éve). - Limes. 2-3. 7-19. 0.

Beluszky P. (1999) Magyarország településhálózata. Pécs, JPTE.

Berényi I.-Dővényi Z. (1996) Historische und aktuelle Entwicklungen des ungarischen Siedlungsnetzes. Stadte und Stadtesysteme in Mittel- und Südosteuropa. - Mayr, A.-Grimm, F. (Hrsg), Leipzig, Institut für Länderkunde.

Enyedi Gy. (1994) Terilletfejlesztés, regionális átalakulás a posztszocialista Magyarországon. - Társadalmi Szemle. 8-9. 133-139. o.

Enyedi Gy. (1996) Regionális folyamatok Magyarországon. Budapest, Hilscher Rezsó Szociálpolitikai Egyesulet.

Erlich É.-Révész G.-Tamási P. (1994) Kelet-Közép-Európa - honnan, hová? - Budapest,

Horváth Gy. (1997a) Európai integráció, keleti bövités és a magyar regionális politika. - Tér és Társadalom. 3. 17-56. 0.

Horváth Gy. (1997b) Fejlettségi kủlőnbségek és fejlesztési politikák az Egyesült Királyságban és Írországban. Regionális átalakulás a Brit-szigeteken. - Horváth Gy. (szerk.), Pécs, MTA RKK.

Nemes Nagy J. (1995) Soprontól Nyíradonyig. Városok a piacgazdasági átmenetben. - Comitatus, 8-9. 15-22. o.

Nemes Nagy J. (1996) Centrumok és perifériák a piacgazdasági átmenetben. - Földrajzi Közlemények. 1. 31-48. 0 .

O’ Malley, E. (1997) A kulfơldi tơke szerepe az ir iparositásban. Regionális átalakulás a Brit-szigeteken. - Horváth Gy. (szerk.), Pécs, MTA RKK.

Rechnitzer J. (1998a) Charakteristika und zukünftige Entwicklungsphasen regionaler Prozesse in Ungarn. Ungarn in Europa. Gesellschaftlicher und raumstruktureller Wandel in Vergangangenheit und Gegenwart. - Volker, A.-Mezösi, G. (Hrsg), Frankfurt am Main, Institut fur Didaktik der Geographie.

Rechnitzer J. (1998b) A határ menti városok aranypatkója. Előadás vázlat. Elhangzott: Az Alfold a XXI. század küszöbén c. konferencián. Békéscsaba, november 12-13.

Ruttkay É. (1995) Nemzeti regionális fejlesztés - az Európai Unióval való harmonizáció és forrásharmonizáció Spanyolország példáján. - Falu-város-régió. 7-8. 21-23. o.

Ruttkay É. (1998) A teruletfejlesztés finanszírozási rendszere az EU csatlakozás tủkrében. -Tér és Társadalom. 1-2. 13-37. o.

\section{HUNGARIAN URBAN NETWORK AND THE EU ACCESSION}

\section{PÁL BELUSZKY - RÓBERT GYŐRI}

The conditions, inducements and directions of the development and shaping of urban stock and network changed radically at different times in the last fifty years in Hungary. These processes can take new way about the preparation and fulfilment of EU accession.

The main conditions and features of the development of urban network before 1990:

- the "top-down" control,

- the homogenisation and concentrated development of city stock, 
- the „model near" pursue,

- the strong hierarchical process, spatial difference catching to settlement hierarchy.

After 1990:

- settlements enter ,settlement" market, location of individual institution is dominated by conditions of competitive market,

- the regional structure of the country and the background of settlement development has been transformed,

- the significance of administration levels to city development has been decreased (the importance of city title and the distributor role of counties has been depreciated),

- the difference between budget supports has been reduced,

- the role of national concepts has been decreased in settlement development process.

The paper review the state of the Hungarian urban network shaped under this terms in the 1990s (town hierarchy, dynamic of towns, town types), and enumerate the expectable effects of EU accession. It shows that ,town competition" is increasing (for obtainable supports), the role of county seats wills probably decrease, and the differences between the towns in respect of development level may get larger. 